Western University

Scholarship@Western

Law Publications

Law School

$9-2012$

\title{
Women and Girls Fleeing Conflict: Gender and the Interpretation and Application of the 1951 Refugee Convention
}

Valerie Oosterveld

Western Law

Follow this and additional works at: https://ir.lib.uwo.ca/lawpub

Part of the Human Rights Law Commons, Immigration Law Commons, Law and Gender Commons, and the Military, War, and Peace Commons

Citation of this paper:

UN High Commissioner for Refugees (UNHCR), Women and Girls Fleeing Conflict: Gender and the Interpretation and Application of the 1951 Refugee Convention, September 2012, PPLA/2012/06 


\title{
LeGal AND Protection Policy RESEARCH SERIES
}

\section{Women and Girls Fleeing Conflict: Gender and the Interpretation and Application of the 1951 Refugee Convention}

\author{
Valerie Oosterveld* \\ University of Western Ontario Faculty of Law, Canada
}

Division of INTERNATIONAL PROTECTION

SEPTEMBER 2012 


\section{DiVision OF INTERNATIONAL PROTECTION \\ UNITED NATIONS HIGH COMMISSIONER FOR REFUGEES (UNHCR) \\ CP2500, 1211 Geneva 2 \\ Switzerland}

E-mail: hqpr02@unhcr.org

Website: www.unhcr.org

This paper was commissioned in September 2011 in the context of a project on Developing Guidelines for the protection of people fleeing violence and conflict across borders.

The opinions expressed in this paper are those of the authors and do not necessarily represent the position of the United Nations or the United Nations High Commissioner for Refugees. This paper may be freely quoted, cited and copied for academic, educational or other non-commercial purposes without prior permission from UNHCR, provided that the source and authors are acknowledged. The paper is available online at http://www.unhcr.org/pages/4a16b17a6.html.

* The author wishes to thank Alexandra MacKenzie for her valuable research assistance, and UNHCR's Sanne Andersen, Alice Edwards and Gisela Thater, as well as Margaret Martin, for their very helpful suggestions and comments. Any errors are the author's own.

(c) United Nations High Commissioner for Refugees 2012. 
I INTRODUCTION ................................................................................................................... 4

1 METHODOLOGY AND SCOPE …………………........................................................................ 7

2 TERMINOLOGY AND CONCEPTS ………………................................................................. 9

II CHARACTER AND EFFECTS OF CONFLICT ON WOMEN AND GIRLS ..................................... 11

III PERSECUTION............................................................................................................................................. 19

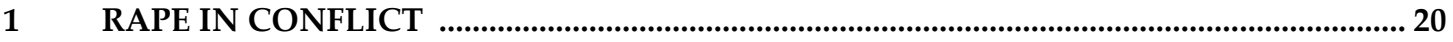

2 OTHER FORMS OF SEXUAL VIOLENCE IN CONFLICT ....................................................... 26

3 OTHER FORMS OF GENDER-RELATED ILL-TREATMENT IN CONFLICT ..................... 27

4 INDISCRIMINATE VERSUS TARGETED GENDER- RELATED ILL-TREATMENT...... 29

$5 \quad$ LESSONS LEARNED........................................................................................................................ 31

IV CONVENTION GROUNDS ………............................................................................................... 32

1 MEMBERSHIP OF A PARTICULAR SOCIAL GROUP ............................................................ 33

2 POLITICAL OPINION AND THE REMAINING CONVENTION GROUNDS ................ 37

$3 \quad$ LESSONS LEARNED ........................................................................................................................ 39

V LACK OF STATE PROTECTION ........................................................................................................... 39

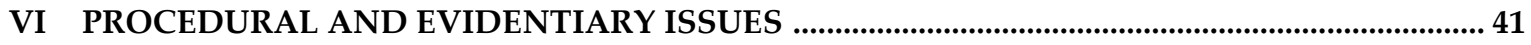

1 COUNTRY OF ORIGIN INFORMATION ……………............................................................... 41

2 CREDIBILITY ISSUES ............................................................................................................... 43

$3 \quad$ LESSONS LEARNED .................................................................................................................. 44

VII CONCLUSIONS .................................................................................................................................... 45 


\section{INTRODUCTION}

Women, girls, men and boys all suffer when exposed to the effects of conflict. Sometimes women and girls have similar experiences in these situations as men and boys. Many times, however, they have different experiences. They may be subjected to different violations because they are women and girls, or they may be subjected to the same type of violations as men and boys, but experience or perceive these harms in a different manner. One obvious example is sexual violence committed during war: "[s]exual violence, and the long shadow of terror and trauma it casts, disproportionately affects women and girls." ${ }^{1}$ This different female experience stems from pervasive global gender inequality: around the world, women and girls tend to be poorer and receive less education, and are often less mobile as a result of traditional family and caregiving responsibilities, all of which negatively compound their experiences during conflict. ${ }^{2}$ While women and girls may have common experiences based on their gender, sometimes girls suffer additional targeted harm as a result of their young age. For example, girls forcibly recruited to serve as fighters may serve in combat and as scouts (like boys), but may also be subjected to sexual slavery and conjugal slavery (unlike boys). ${ }^{3}$

When women and girls fleeing conflict become asylum-seekers, are their genderdifferentiated experiences recognized by decision-makers? It is not immediately obvious that they would be, given that neither the terms 'sex' nor 'gender' appear in the definition of 'refugee' set out in the 1951 Convention Relating to the Status of Refugees, as amended by the 1967 Protocol $^{4}$ (the 'Refugee Convention' or 'Convention'). ${ }^{5}$ However, over the past

\footnotetext{
${ }^{1}$ Report of the United Nations Secretary-General, 'Conflict-related sexual violence,' 13 January 2012, S/2012/33, para. 6 .

${ }^{2}$ Committee on the Elimination of Discrimination Against Women, 'Concept Note: General Discussion on the protection of women's human rights in conflict and post-conflict contexts', 18 July 2011, available online at http://www2.ohchr.org/english/bodies/cedaw/docs/GRConceptNote.pdf, 6-7.

${ }^{3}$ These views were provided by Radhika Coomaraswamy, United Nations Special Representative of the Secretary-General for Children and Armed Conflict, as expert evidence in: Prosecutor v. Lubanga, Situation in the Democratic Republic of the Congo, Case No. ICC-01/04-01/06, Transcript ICC-01/04-01/06-T-223-ENG, 7 January 2010, 29 line 25 and 30 lines 1-9.

${ }^{4}$ Convention Relating to the Status of Refugees (entered into force 22 April 1954) 189 UNTS 137 (Refugee Convention) [Refugee Convention]; Protocol relating to the Status of Refugees (entered into force 4 October 1967) 606 UNTS 267 (Protocol) [Refugee Protocol]. The Refugee Convention recognizes as refugees persons who, "owing to [a] well-founded fear of being persecuted for reasons of race, religion, nationality, membership of a particular social group or political opinion" are outside the country of his or her nationality and are unable or, owing to such fear, are unwilling to avail themselves of the protection of that country, .Art. 1A(2), as amended by Art. 1(2) of the 1967 Protocol, Refugee Protocol.
} 
twenty years, there has been a significant focus at the international level on ensuring a gender-sensitive interpretation of the refugee definition. A sampling of these efforts includes the issuance by UNHCR of a number of groundbreaking guidance documents, such as the 1991 "Guidelines on the Protection of Refugee Women" (updated in 2008), ${ }^{6}$ the 1995 "Sexual Violence Against Refugees: Guidelines on Prevention and Response" (updated in 2003), ${ }^{7}$ the 2002 "Guidelines on Gender-Related Persecution" 8 and various Conclusions by the Executive Committee. 9 "[I]n recognition of the fact that women refugees often experience persecution differently from refugee men", ${ }^{10}$ various States have adopted guidelines on female asylum-seekers, such as Australia, ${ }^{11}$ Canada, ${ }^{12}$ the Netherlands, ${ }^{13}$ Norway, ${ }^{14}$ South Africa, ${ }^{15}$ the United Kingdom ${ }^{16}$ and the United States. ${ }^{17}$ Some States take a different approach and have included 'sex' or 'gender' in the list of Convention grounds in their domestic legislation. ${ }^{18}$

${ }^{5}$ On the history of this, see A. Edwards, 'Transitioning Gender: Feminist Engagement with International Refugee Law and Policy 1950-2010' (2010) 29(2) Refugee Survey Quarterly 21, 22-23.

${ }^{6}$ UNHCR, 'Guidelines on the Protection of Refugee Women,' July 1991, UN Doc. EC/SCP/67, paras 54-56 and 59-60 [UNHCR, 'Guidelines on the Protection of Refugee Women']. These guidelines were updated in 2008. See UNHCR, 'Handbook for the Protection of Women and Girls', January 2008, available online at http://www.unhcr.org/refworld/docid/47cfc2962.html [UNHCR, 'Handbook'].

${ }^{7}$ UNHCR, 'Sexual Violence Against Refugees: Guidelines on Prevention and Response', 8 March 1995, available online at http://www.unhcr.org/refworld/docid/3ae6b33e0.html , 3; UNHCR, 'Sexual and Genderbased Violence Against Refugees, Returnees and Internally Displaced Persons: Guidelines on Prevention and Response' (May 2003), available online at http://www.unhcr.org/3f696bcc4.html.

${ }^{8}$ UNHCR, 'Guidelines on International Protection No.1 - Gender-Related Persecution within the context of Article 1A(2) of the 1951 Convention and/or its 1967 Protocol relating to the Status of Refugees', 7 May 2002, HCR/GIP/02/01, available online at http://www.unhcr.org/refworld/docid/3d36flc64.html, para. 6 [UNHCR, 'Guidelines on International Protection No. 1: Gender-Related Persecution'].

${ }^{9}$ E.g., UNHCR ExCom, 'Refugee Women and International Protection', 18 October 1985, Conclusion No. 39 (XXXVI) 1985, available online at http://www.unhcr.org/3ae68c43a8.html, para. (k); UNHCR ExCom, 'Refugee Protection and Sexual Violence', 8 October 1993, Conclusion No. 73 (XLIV) 1993, available online at http://www.unhcr.org/3ae68c6810.html [UNHCR ExCom, 'Refugee Protection'].

${ }^{10}$ UNHCR ExCom, Refugee Protection, note 9 above, para. (e).

${ }^{11}$ Guidelines on Gender Issues for Decision Makers 1996 (Australia) and Gender Guidelines 2012 (Australia).

${ }^{12}$ Guidelines for Women Refugee Claimants Fearing Gender-Related Persecution 2003 (Canada) [Canada, 'Guidelines for Women Refugee Claimants'].

${ }^{13}$ Aliens Act Implementation Guidelines 2000 (Netherlands).

${ }^{14}$ Guidelines - Persecution for Other Reasons 1998 (Norway).

${ }^{15}$ Gender Guidelines for Asylum Determination 1999 (South Africa).

${ }^{16}$ Asylum Gender Guidelines 2000 (United Kingdom) and Gender Issues in the Asylum Claim 2006 (United Kingdom).

${ }^{17}$ Considerations for Asylum Officers Adjudicating Asylum Claims From Women 1995 (United States) and Gender Guidelines for Overseas Refugee Processing 2000 (United States).

${ }^{18}$ Refugee Act 1996 (Ireland), s. 1 (in defining membership of a particular social group); and Refugee Act 1998 (South Africa), ch. 1(1), also defining membership of a particular social group. Spain's Equality Act (2007) included within the definition of 'refugee' "foreign women who are fleeing from their countries of 
Given all of this guidance, one would expect a gender-sensitive determination of asylum claims by women and girls fleeing conflict. However, numerous studies show that there are still deep flaws in the domestic consideration of refugee claims by women and girls, and a need for improvement in both policy and practice. ${ }^{19}$ To date, this analysis has not concentrated specifically on women and girls who have fled conflict. This paper therefore aims to bring some preliminary focus to this sub-set of female refugee claimants, by asking three interrelated questions. The first question is: can violence directed against women and girls during conflict ever be described as indiscriminate (and therefore not persecutory for the purposes of the Refugee Convention)? The second question is: on what legal basis, if any, could a woman or girl fleeing conflict meet the definition of 'refugee'? The final question is: what problems do women and girls fleeing conflict face when making refugee claims, and are these problems different from those faced by female claimants fleeing peacetime illtreatment?

This paper begins by clarifying the methodology and scope of the paper, as well as key concepts used throughout. Part 2 of this study sets out the character and effects of conflict on women and girls, especially the physical, psychological, social and economic experiences that may differ from those of men and boys. By examining potential commonalities in female experiences of conflict, this Part endeavors to demonstrate that the so-called 'indiscriminate' nature of ill-treatment in conflict may not be so indiscriminate after all. Part 3 explores when conflict-related ill-treatment has been recognized as persecution, and when it has not,

origin due to a justified fear of suffering persecution on the grounds of gender" at 65: Constitutional Act 3/2007 of 22 March for effective equality between women and men (Organic Law 3/2007), 2007 (Spain) [Spain, Equality Act]. For additional examples, see: A. Edwards, 'Age and Gender Dimensions in International Refugee Law', in E. Feller, V. Turk and F. Nicholson, eds., Refugee Protection in International Law: UNHCR's Global Consultations on International Protection (Cambridge: Cambridge University Press, 2003), 56 at n. 50 [Edwards, 'Age and Gender Dimensions'].

${ }^{19}$ E.g., C. Querton, "I Feel Like as a Woman I'm Not Welcome': A Gender Analysis of UK Asylum Law, Policy and Practice', Asylum Aid, January 2012, available online at http://www.asylumaid.org.uk/pages/i feel like as a woman.html [Querton, 'I Feel Like']; H. Muggeridge and C. Maman, 'Unsustainable: The Quality of Initial Decision-Making in Women's Asylum Claims', Asylum Aid, January 2011, available online at http://www.asylumaid.org.uk/data/files/unsustainableweb.pdf [Muggeridge and Maman, 'Unsustainable']; H. Cheikh Ali, C. Querton and E. Soulard, 'Gender-Related Asylum Claims in Europe: A Comparative Analysis of Law, Policies and Practice Focusing on Women in Nine EU Member States', GENSEN, May 2012, available online at http://www.asylumaid.org.uk/data/files/Genderrelated asylum claims in Europe.pdf [Cheikh et al.]; Human Rights Watch, 'Fast-Tracked Unfairness: Detention and Denial of Women Asylum Seekers in the UK', 2010, available online at http://www.hrw.org/sites/default/files/reports/uk0210webwcover.pdf [HRW, 'Fast-Tracked']; and UNHCR, 'Improving Asylum Procedures - Comparative Analysis and Recommendations for Law and Practice: Key Gender Related Findings and Recommendations', March 2010, available online at http://www.unhcr.org/refworld/docid/4be01ed82.html [UNHCR, 'Improving Asylum Procedures Gender']. 
thereby beginning the discussion of the legal basis on which a woman or girl fleeing conflict can meet the definition of 'refugee'. The issue of whether ill-treatment in conflict can be considered to be targeted at individual women and girls is also examined. Part 4 examines the Convention grounds most often used in refugee claims made by women and girls fleeing conflict, according to the case set described in section 1.1. below: membership of a particular social group, political opinion, race and religion. Part 5 discusses how lack of State protection has been considered in female conflict-related refugee claims. Part 6 discusses procedural and evidentiary problems that arise in asylum claims by women and girls fleeing conflict, especially with respect to credibility gaps on sexual violence and lack of genderspecific country of origin information. Part 7 ends with concluding observations on the themes raised by the questions above: first, the need for a deeper understanding of persecution; second, the need for expanded conceptions of the Convention grounds as they relate to women and girls fleeing conflict; and third, that women and girls fleeing conflict face problems similar to those making peacetime-related claims, but also face specific conflict-related evidentiary and procedural hurdles.

\section{METhODOLOGY AND SCOPE}

This paper explores how refugee adjudicators have considered cases involving women and girls who have fled conflict, or whose claims relate to conflict, mainly through an examination of 46 cases decided between 2004 and 2012 in Australia, Canada, New Zealand, the United Kingdom and the United States. These cases involve Afghanistan, Angola, Bosnia-Herzegovina, Burundi, Chad, Colombia, Côte d'Ivoire, the Democratic Republic of the Congo (DRC), Ethiopia, Guinea, Iraq, Palestine, Republic of Congo, Rwanda, Serbia, Somalia, Sri Lanka and Uganda. These cases come from various levels of the refugee determination process, from initial determinations to final appeals. All of the cases have

some relation to conflict. Some are directly about women and girls fleeing the effects of conflict that had spread to the area in which they were living. Others are about actions of parties to a conflict. Yet others are about ongoing violence that was predated by an armed conflict and may or may not be considered an armed conflict at the date of the refugee determination, but which nonetheless come close to the international humanitarian law (IHL) threshold of armed conflict. This latter group was included because these cases were considered to provide helpful insight into how refugee claims by women and girls are similar in both armed conflict and other situations of violence below the IHL threshold of armed conflict.

Each of these 46 cases were analyzed so as to identify: whether the conflict figured prominently or not in the discussion of the refugee claim; the Convention ground(s) considered and whether those ground(s) related either explicitly or inherently to gender; 
whether gender was considered in the discussion of past and/or potential future persecution; whether there were any gender-related procedural issues; and whether there were any gender-related evidentiary issues (for example, with respect to country of origin information). In addition to these 46 cases, this paper also refers to a number of other cases involving female claimants coming from countries involved in conflict. These additional cases are usually from other jurisdictions or outside of the time period of the case set, and are used to illustrate key points. This study places the examination of case law within the larger discussion by international organizations (including UNHCR), nongovernmental organizations, scholars and others on the determination of refugee claims by women and girls and the consideration of gender-based persecution within international refugee law. While the focus of this paper is on the juncture of (part of) gender ${ }^{20}$ and conflict, the rich literature on the wider issues of female refugee claims and on gender-based persecution is necessarily important: the barriers faced by women and girls making claims based on conflict are a subset of the difficulties many female claimants have, regardless of the reason for their flight.

Finally, it is important to note that there is relatively little existing published research specifically on the lessons to be learned about female refugee claims stemming from conflict and, as a result, this study is necessarily preliminary in nature. The scholarship on genderrelated asylum claims tends to focus on female claims of female genital mutilation, forced marriage, domestic violence, 'honour' crimes, rape and other forms of sexual violence, trafficking into forced prostitution or forced labour, forced sterilization or forced abortion, and transgression of social mores, or both male and female claims related to sexual orientation and gender identity. ${ }^{21}$ Within these categories, conflict tends only to be discussed in relation to refugee claims based on sexual violence. While an examination of sexual violence is important, it usually does not represent the totality of the female experience of conflict.

This paper does not focus on gender issues raised in refugee claims by men and boys fleeing armed conflict, though these are important and often overlooked issues that require further

\footnotetext{
${ }^{20}$ It is important not to elide women and girls with the term 'gender': see the discussion of terminology in section 1.2.

${ }^{21}$ E.g., K. Musalo, J. Moore and R. Boswell, Refugee Law and Policy: A Comparative and International Approach (Durham, North Carolina: Carolina Academic Press, $4^{\text {th }}$ ed., 2011), 689-820 considers repressive social norms, rape, female genital cutting (FGC), and persecution to others (such as FGC) as persecution to self; H. Crawley, Refugees and Gender: Law and Process (UK: Jordan Publishing Ltd., 2001), 79-198, covers women's political participation, gendered social mores and the concept of 'honour', violence within the family, reproductive rights including forced sterilization and abortion, sexual orientation and female genital mutilation.
} 
study. ${ }^{22}$ This paper also does not explore exclusion under Article 1(F) of the Refugee Convention. This paper also does not discuss the potential or actual implications of the broader refugee definitions at the regional level for women and girls claiming asylum from a situation involving armed conflict. Finally, it does not discuss the issue of subsidiary or complementary protection for women and girls fleeing conflict. ${ }^{23}$

\section{TERMINOLOGY AND CONCEPTS}

This study uses the term 'gender'. Since the term tends to be misused at the international level as a synonym for 'women' or 'female' only, ${ }^{24}$ it is important to be clear in its meaning. UNHCR has defined 'gender' as "the relationship between women and men based on socially or culturally constructed and defined identities, status, roles and responsibilities that are assigned to one sex or another." ${ }^{25}$ Even though gender is a societal or cultural norm, it is not static or innate and its meaning can change over time. ${ }^{26}$ While gender norms may evolve over generations, sometimes they can change very quickly, including during times of great upheaval, such as during conflict. ${ }^{27}$ Since this paper focuses on the experiences of female refugee claimants fleeing conflict, it will mostly be discussing socially- or culturallyconstructed gender norms of femaleness, often perceived in contradistinction to social and cultural norms around maleness.

This paper also uses the terms 'sexual violence' and 'gender-based violence'. Sexual violence is a form of gender-based violence. Conflict-related sexual violence has been described as "acts of sexual violence that are linked with military/political objectives and that serve (or intend to serve) a strategic aim related to the conflict." ${ }^{28}$ Sexual violence is also considered to

\footnotetext{
22 Edwards, 'Transitioning Gender', note 5 above, 40-44.

23 This requires more study, as subsidiary/complementary protection status is sometimes used as a 'safety valve' for gender cases, avoiding the gender analysis on Convention grounds, thus subverting the primacy of the Convention grounds: Cheikh et al., note 20 above, 57.

${ }^{24} \mathrm{H}$. Charlesworth, 'Not Waving but Drowning: Gender Mainstreaming and Human Rights in the United Nations' (2005) 18 Harvard Human Rights Journal 1, 14-15.

${ }^{25}$ UNHCR, Guidelines on International Protection No. 1: Gender-Related Persecution', note 8 above, para. 3. Other parts of the United Nations have adopted similar definitions: e.g. UNICEF, UNFPA, UNDP and UN Women, 'Gender Equality, UN Coherence \& You: Glossary', available online at http://www.unicef.org/gender/training/content/resources/Glossary.pdf.

${ }^{26}$ UNHCR, Guidelines on International Protection No. 1: Gender-Related Persecution', note 8 above, para. 3.

${ }^{27}$ For example, in some cases, women are recruited into resistance groups and acquire rights and status as fighters that they had never previously enjoyed: J. G. Gardam and M. J. Jarvis, Women, Armed Conflict and International Law (The Hague: Kluwer Law International, 2001), 50. Unfortunately, these changes in gender norms often disappear post-conflict: ibid., 51.

${ }^{28}$ United Nations Department of Political Affairs, 'Guidance for Mediators: Addressing Conflict-Related Sexual Violence in Ceasefire and Peace Agreements', January 2012, available online at
} 
be linked to conflict when it is committed against civilians in the context of a conflict, committed in and around UN-managed refugee and internally displaced persons camps, or committed during disarmament, demobilization and reintegration processes. ${ }^{29}$ This paper uses the term 'gender-based violence' to capture ill-treatment influenced by the social construction of maleness and femaleness in a given society or culture. That ill-treatment may or may not have a sexual component.

This study also uses the term 'conflict'. Under IHL, there are two types of armed conflict. International armed conflict is conflict occurring between two or more States, in which one or more States have recourse to armed force against another State, "regardless of the reasons or the intensity of this confrontation". 30 'Non-international armed conflict' - also known as 'internal armed conflict' - refers to armed conflicts not of an international character occurring within the territory of a State. ${ }^{31}$ More clearly, the term refers to:

protracted armed confrontations occurring between governmental armed forces and the forces of one or more armed groups, or between such groups arising on the territory of a State [party to the Geneva Conventions]. The armed confrontation must reach a minimum level of intensity and the parties involved must show a minimum [degree] of organization. ${ }^{32}$

While this study uses the term 'conflict' to capture the violence within both international and non-international armed conflicts, it also uses the term to capture situations near, but not necessarily at, the threshold of non-international armed conflict as understood under IHL. In other words, the term 'conflict', as used in this study, is meant to go somewhat beyond the strict legal boundaries of IHL. This is done in order to reflect the reality of the lives of women and girls fleeing conflict: the types of persecution they face that may be considered

http://www.un.org/wcm/webdav/site/undpa/shared/undpa/pdf/DPA\%20Guidance\%20for\%20Mediators $\% 2$ 0on $\% 20$ Addressing $\% 20$ Conflict-

Related\%20Sexual\%20Violence\%20in\%20Ceasefire\%20and\%20Peace\%20Agreements.pdf， 5 [UN DPA, 'Guidance for Mediators'].

${ }^{29}$ Ibid.

${ }^{30}$ International Committee of the Red Cross, 'How is the Term "Armed Conflict" Defined in International Humanitarian Law? International Committee of the Red Cross Opinion Paper', March 2008, available online at http://www.icrc.org/eng/assets/files/other/opinion-paper-armed-conflict.pdf, 1 [ICRC, 'How is the Term']. The definition of 'international armed conflict' also includes conflicts in which peoples are fighting against colonial domination, alien occupation or racist regimes in the exercise of their right to self-determination: Protocol Additional to the Geneva Conventions of 12 August 1949 and Relating to the Protection of Victims of International Armed Conflicts, 1125 UNTS 3 (8 June 1977), Art. 1(4).

${ }^{31}$ E.g., Geneva Convention of 1949 Relative to the Protection of Civilian Persons in Time of War (entered into force 21 October 1950) 75 UNTS 287 (12 August 1949) (Fourth Geneva Convention), art. 3.

${ }^{32}$ ICRC, 'How is the Term', note 30 above, 5. 
as conflict-related may begin before the legal threshold between internal disturbances and armed conflict is crossed and may continue through to post-conflict. ${ }^{33}$ In other words, in some cases, it may not be useful to make bright line distinctions when it is unclear whether the conflict being considered is just under or at the IHL threshold and that threshold is not important for describing the ill-treatment suffered. On the other hand, there may indeed be cases where it is useful to invoke the IHL threshold: for example, where the classification of rape, sexual slavery, enforced prostitution, forced pregnancy, enforced sterilization, and other forms of sexual violence as war crimes ${ }^{34}$ would assist in their identification as persecution. ${ }^{35}$

\section{CHARACTER AND EFFECTS OF CONFLICT ON WOMEN AND GIRLS}

Conflict has wide-ranging physical, psychological, social and economic impacts on the lives of women and girls. ${ }^{36}$ This Part outlines some of these effects as an overview of the types of experiences that might form the basis of a refugee claim. However, it is important to note at the outset that the experiences of individual women and girls in conflict vary and are influenced by a range of factors, such as age, race, ethnicity, nationality, class, disability, sexuality and gender identity. These factors may make individual women and girls more or less vulnerable in a particular conflict. ${ }^{37}$ It is also important to understand that the impact of a conflict is interlinked with the status of women and girls in a given society prior to the conflict: "the additional layer of preexisting exclusions and discrimination that typify women's status in many societies has an additional and compounding effect on the waging of and experiences that follow from war in conflicted societies". ${ }^{38}$ This is because armed conflict tends to exacerbate gender inequality. ${ }^{39}$ For example, women and girls face violence

\footnotetext{
${ }^{33}$ F. Ní Aolaín, D.F. Haynes and N. Cahn, On the Frontlines: Gender, War, and the Post-Conflict Process (New York: Oxford University Press, 2011), 28 [Ní Aolaín et al.], 46.

34 This list comes from the Rome Statute of the International Criminal Court (entered into force 1 July 2002) 2187 UNTS 90 (Rome Statute), arts. 8(2)(b)(xxii) and 8(2)(e) (vi) [Rome Statute].

35 The same observations were noted at UNHCR and the International Criminal Tribunal for Rwanda, Expert Meeting on Complementarities between International Refugee Law, International Criminal Law and International Human Rights Law: Summary Conclusions, July 2011, available at: http://www.unhcr.org/refworld/docid/4e1729d52.html.

${ }^{36}$ M. Eriksson, Defining Rape: Emerging Obligations for States under International Law? (Boston: Martinus Nijhoff Publishers, 2011) 125. See also UNSC Res. 1820 (2008), 19 June 2008 [Resolution 1820] preambular para. 6 .

${ }^{37}$ Gardam and Jarvis, note 27 above, 19.

${ }^{38}$ Ní Aolaín et al., note 33 above, 28.

${ }^{39}$ Gardam and Jarvis, note 27 above, 21.
} 
(such as domestic violence) during peacetime in every country in the world, ${ }^{40}$ but the presence of an armed conflict tends to escalate the types and levels of physical and psychological violence they face because of the breakdown of law and order, increase in availability of small arms and light weapons, and loss of family and community protection. ${ }^{41}$ It also tends to have a severely negative impact on their economic and social well-being - for example, interrupted access to survival goods makes it difficult for women to care for themselves and their families. ${ }^{42}$

Even though individual women and girls may experience conflict differently because of different intersectionalities, it is possible to identify a range of ways in which there may be a 'female' experience of conflict. This experience may be entirely different from that of men and boys, or it may overlap with that of men and boys but be expressed in a gendered way. For example, both males and females are at risk of dying in an armed conflict, but women and girls may be directly targeted for death, death threats or torture for challenging the socially-constructed gender norms of a society, ${ }^{43}$ or as a result of the political or military activities of their male relatives or friends. ${ }^{44}$ Or, women and girls may be caught in the crossfire or seen as dispensable 'cannon fodder' by forces on all sides. ${ }^{45}$ They may be used as civilian human shields to try to deter the other side from attacking a military installation. ${ }^{46}$ The traditional role of women and girls as caregivers for the family (including the elderly, sick and the young) may make it more difficult to escape dangerous circumstances and sometimes results in death from being caught in the midst of a battle between opposing forces or fleeing into areas with landmines. ${ }^{47}$

Women and girls also may witness death in a gender-related manner. The Special Court for Sierra Leone recorded many stories of women and girls forced to watch their loved onesoften male relatives such as husbands-be killed by the rebels, as a form of severe

${ }^{40}$ B. Meyersfeld, Domestic Violence and International Law (Oxford: Hart Publishing, 2010), 1.

${ }^{41}$ Gardam and Jarvis, note 27 above, 25.

${ }^{42}$ Ibid.

${ }^{43}$ International Center for Transitional Justice, 'Across the Lines: the Impact of Nepal's Conflict on Women', December 2010, available online at http://www.ictj.org/publication/across-lines-impact-nepals-conflictwomen , 46-47 [ICTJ, 'Across the Lines'].

${ }^{44}$ In Nepal, wives of government officials or security personnel were subjected to rape and torture: ibid., 47. See also: Amnesty International, 'This is What We Demand. Justice! Impunity for Sexual Violence Against Women in Colombia's Armed Conflict', September 2011, available online at http://www.amnesty.org/en/library/info/AMR23/018/2011/en , 32 [Amnesty International, 'Colombia'].

${ }^{45}$ Gardam and Jarvis, note 28 above, 22.

${ }^{46}$ Human Rights Watch, 'Human Rights Watch Testimony to International Tribunal on Crimes Against Women in Burma', 27 June 2010, available online at http://www.hrw.org/news/2010/06/27/human-rightswatch-testimony-women-s-tribunal.

${ }^{47}$ Gardam and Jarvis, note 28 above, 22 and 24. 
psychological torture. ${ }^{48}$ This was a way for the rebels to terrorize the civilian population into submission. ${ }^{49}$ As well, many women and girls suffer the death or disappearance of male family members during conflict, ${ }^{50}$ causing "immeasurable emotional, social and economic suffering for the women who are left to reconstruct their lives following the conflict." 51

Women and girls are also vulnerable to physical and psychological violations during conflict. The most well-known form of violence directed against women and girls because of their gender is sexual violence, which can take many forms. Rape is perhaps the most notorious, and it comes in many permutations: women and girls may be raped by one person in private (for example, when a soldier searches a house), ${ }^{52}$ raped in public, raped by multiple people, or forced to participate in sexual intercourse or other sexual acts with family members or fellow civilians. ${ }^{53}$ The reduced presence of men in households during times of conflict means that security forces and private individuals may opportunistically target women and girls for rape. ${ }^{54}$ Other forms of sexual violence include sexual slavery, ${ }^{55}$ forced prostitution, sexual mutilation, sexual humiliation, ${ }^{56}$ unwanted sexual touching ${ }^{57}$ and being compelled to exchange sex for essential items or any other reason. ${ }^{58}$

\footnotetext{
${ }^{48}$ Prosecutor v. Sesay et al., Case No. SCSL-04-15-T, Trial Judgment, 9 March 2009, paras 1194, 1347 [Sesay Trial Judgment].

49 Ibid., paras 1352, 1356.

${ }^{50}$ For example, during the conflict in the former Yugoslavia, women, children and the elderly in Srebrenica were separated from male family members above the age of approximately 16 . Thousands of these men and boys were then killed: Prosecutor v. Krstic, Case No. IT-98-33-T, Trial Judgment, 2 August 2001, paras 633636, 644-645; Prosecutor v. Popović et al., Case No. IT-05-88-T, 10 June 2010, paras 837, 841, 856-863.

${ }^{51}$ Gardam and Jarvis, note 27 above, 37 and 39, footnotes omitted; ICTJ, 'Across the Lines', note 43 above, 28; Human Rights Watch, 'At a Crossroads: Human Rights in Iraq Eight Years After the US-Led Invasion', 21 February 2011, available online at http://www.hrw.org/reports/2011/02/21/crossroads, 22-23 [HRW, 'At a Crossroads'].

52 The Trial of Jean-Pierre Bemba Gombo, 'Witness: Bemba's Soldiers Raped Me, Stole Our Goats, Shot Our Dog', 20 November 2010, available online at http://www.bembatrial.org/2010/11/witnessbemba $\%$ E2\%80\%99s-soldiers-raped-me-stole-our-goats-shot-our-dog/.

53 Sesay Trial Judgment, note 48 above, para. 1347.

54 ICTJ, 'Across the Lines', note 43 above, 46.

55 During WWII, more than 200,000 girls and women were enslaved in so-called 'comfort stations' associated with the Japanese Imperial Army throughout Asia: UN Economic and Social Council, Commission on Human Rights, 'Contemporary Forms of Slavery, Systematic Rape, Sexual Slavery and Slavery-like Practices During Armed Conflict: Update to the Final Report Submitted by Ms. Gay J. McDougall, Special Rapporteur,' 6 June 2000, UN Doc. E/CN.4/Sub.2/2000/21, para. 71; UN Economic and Social Council, Commission on Human Rights, 'Contemporary Forms of Slavery, Systematic Rape, Sexual Slavery and Slavery-like Practices During Armed Conflict: Final Report Submitted by Ms. Gay J. McDougall, Special Rapporteur', 22 June 1998, UN Doc. E/CN.4/Sub.2/1998/13, app. para. 1.

${ }^{56}$ Gardam and Jarvis, note 27 above, 25, citing to M. Goldenberg, 'Memoires of Auschwitz Survivors' in D. Ofer and L. Weitzman, eds, Women and the Holocaust (New Haven: Yale University Press, 1998), 330-331,
} 
During conflict, no place is entirely safe for women and girls. Families may flee to protect the females in the family from rape, or girls may be married off by their families at a young age in an attempt to protect them from conflict-related sexual violence. ${ }^{59}$ However, these attempts at protection do not always succeed because conflict-related sexual violence can occur in many places: at roadblocks, ${ }^{60}$ in one's own house, ${ }^{61}$ in fields, ${ }^{62}$ in places of refuge, ${ }^{63}$ in detention centres, ${ }^{64}$ in army barracks, ${ }^{65}$ in public or communal areas, ${ }^{66}$ in refugee camps, ${ }^{67}$ and in places where women and girls are hiding. ${ }^{68}$

The perpetrators of sexual violence are also varied. They may be soldiers from the other "side" of the conflict, ${ }^{69}$ "friendly" forces, ${ }^{70}$ mercenaries, State officials, civilians in situations of control (such as guards at detention facilities), ${ }^{71}$ opportunistic civilians (both known and unknown to the victim) or peacekeepers. ${ }^{72}$

recounting how women were forced to strip naked and lie on tables while SS officers jeered and poked the women's genital with a stick.

${ }^{57}$ For example, in Nepal, young girls reported that security forces did "security checks" on the way to school, which involved touching their breasts and hips and being subjected to verbal abuse: ICTJ, 'Across the Lines', note 43 above, 51.

${ }^{58}$ Gardam and Jarvis, note 27 above, 26.

${ }^{59}$ UN Human Rights Council, 'Report of the International Commission of Inquiry to investigate all alleged violations of international human rights law in the Libyan Arab Jamahiriya', 1 June 2011, UN Doc. A/HRC/17/44, para. 214.

${ }^{60}$ Prosecutor v. Nyiramasuhuko et al., Case No. ICTR-98-42-T, Judgment and Sentence, 24 June 2011, paras 3132-3135, 6076-6088 and 6094.

${ }^{61}$ For examples in Nepal, see ICTJ, 'Across the Lines', note 43 above, 50.

${ }^{62}$ Human Rights Watch, 'Afraid and Forgotten, Lawlessness, Rape and Impunity in Western Côte d'Ivoire', 22 October 2010, available online at http://www.hrw.org/reports/2010/10/22/afraid-and-forgotten-0, 31 [HRW, 'Afraid and Forgotten'].

${ }^{63}$ R c. Munyaneza, 2009 QCCS 2201, at paras. 724-739, 2082-2089 (Canada) [Munyaneza].

${ }^{64}$ Physicians for Human Rights, 'Witness to War Crimes: Evidence from Misrata, Libya', August 2011, available online at http://physiciansforhumanrights.org/library/reports/witness-to-war-crimes.html, 4 and 15 [PHR, 'Witness to War Crimes'].

${ }^{65}$ ICTJ, 'Across the Lines', note 43 above, 52-3.

${ }^{6}$ Prosecutor v. Akayesu, Case No. ICTR-96-4-T, Trial Judgment, 2 September 1998, at paras. 416, 421-422, 429, 437, 449-452 [Akayesu Trial Judgment].

${ }^{67}$ Human Rights Watch, “'Welcome to Kenya”- Police Abuses of Somali Refugees', 17 June 2010, available online at http://www.hrw.org/reports/2010/06/17/welcome-kenya-0, 6-8 [HRW, 'Welcome to Kenya'].

${ }^{68}$ Human Rights Watch, "“We'll Kill You if You Cry": Sexual Violence in the Sierra Leone Conflict', 17 January 2003, available online at http://www.hrw.org/reports/2003/01/16/well-kill-you-if-you-cry, 31.

${ }^{69}$ Amnesty International, 'Mali: Five Months of Crisis, Armed Rebellion and Military Coup' 16 May 2012, available online at http://www.amnesty.org/en/library/info/AFR37/001/2012/en , 5.

${ }^{70}$ ICTJ, 'Across the Lines', note 43 above, 55.

${ }^{71}$ Prosecutor v. Nicolić, Case No. IT-94-2-S, Sentencing Judgment, 18 December 2003, at paras. 21-22.

${ }^{72}$ Advisor on Sexual Exploitation and Abuse by UN Peacekeeping Personnel, 'A comprehensive strategy to eliminate future sexual exploitation and abuse in United Nations peacekeeping operations', 24 March 2005, UN Doc. A/59/710. 
Women and girls may face heightened vulnerability to sexual violence because of the intersection of their sex or gender and other identities. One example can be seen in the 1994 Rwandan genocide: during the genocide, Tutsi women were portrayed in the media as "seductress spies" who needed to be punished through rape. ${ }^{73}$ Another example relates to age-the rape of very young girls has been reported in many conflicts, with far-reaching physical and psychological injuries. ${ }^{74}$ Being an older women does not protect individuals from being raped: for example, Human Rights Watch reported a 78 year old rape victim in Western Côte d'Ivoire. ${ }^{75} \mathrm{And}$, in some places, the very fact of being female-regardless of any other identity-makes one extremely vulnerable. In the Democratic Republic of the Congo, there are no variables (whether education, level of wealth, or area of residence (urban vs. rural)) that provide protection from sexual violence. ${ }^{76}$

Turning now to the wider category of gender-based violence, women and girls may also face violence based upon socially-constructed norms of maleness and femaleness. This violence may or may not have a sexual aspect. For example, since women and girls are often seen as responsible for the home, they may be enslaved to carry out domestic forced labour such as cooking, ${ }^{77}$ cleaning, and laundering. ${ }^{78}$ They may also be forced to porter for opposing or friendly forces. ${ }^{79}$ During the conflict in Sierra Leone, girls and women were abducted or captured and then individually assigned as a 'bush wife' to a rebel soldier or commander. These 'wives' were expected to provide sex on demand and to cook, clean and provide other domestic services: this has been termed 'forced marriage' or conjugal slavery. ${ }^{80}$ In a different

\footnotetext{
${ }^{73}$ Prosecutor v. Nahimana et al., Case No. ICTR-99-52-T, Judgment and Sentence, 3 December 2003, paras 177, 963, 1079.

${ }^{74}$ ICTJ, 'Across the Lines', note 43 above, 55 (rape of a 5 year old). The United Nations Population Fund, in reporting on 15,996 new cases of sexual violence in the Democratic Republic of the Congo in 2008, indicated that $65 \%$ of the victims were under the age of 18, with $10 \%$ under the age of 10: Figures on Sexual Violence Reported in the DRC in 2008 (New York: UN Population Fund, 2009), 1, as cited in Human Rights Watch , 'Soldiers Who Rape, Commanders Who Condone', 16 July 2009, available online at http://www.hrw.org/en/node/84366/section/7, 1. Human Rights Watch reported rape of infants in Western Côte d'Ivoire: HRW, 'Afraid and Forgotten', note 62 above, 32 and 38. See also Amnesty International, 'Colombia', note 44 above, 17.

${ }^{75} \mathrm{HRW}$, 'Afraid and Forgotten', note 62 above, 38.

${ }^{76}$ A. Peterman, T. Palermo and C. Bredenkamp, 'Estimates and Determinants of Sexual Violence Against Women in the Democratic Republic of Congo', (2011) 101:6 American Journal of Public Health 1060.

77 PHR, ‘Witness to War Crimes', note 64 above, 15.

${ }_{78}$ Prosecutor v. Kunarac et al., Case No. IT-96-23-T \& IT-96-23/1-T, Trial Judgment, 22 February 2001, paras. 63, $68,182,188,210,574,751$.

${ }^{79}$ Human Rights Watch, “'Untold Miseries” - Wartime Abuses and Forced Displacement in Burma's Kachin State', 20 March 2012, available online at http://www.hrw.org/reports/2012/03/20/untold-miseries, 36-50.

${ }^{80}$ Sesay Trial Judgment, note 48 above, paras. 1154-1155, 1211, 1213, 1293, 1295, 1412-1413 and 1466-1472; Prosecutor v. Taylor, Case No. SCSL-03-01-T, Trial Judgment, 18 May 2012, paras. 424-430 [Taylor Trial Judgment].
} 
permutation, teenage girls in Nepal were enticed into marriage by security forces personnel stationed in villages and then were subsequently abandoned when the army unit moved on. ${ }^{81}$ These 'conflict wives' and their children have been severely stigmatized. ${ }^{82}$ Additional forms of gender-based violence include forced pregnancy, forced sterilization and forced abortion.

Many seemingly gender-neutral forms of violence are actually gendered in the way they are carried out, or in their effects. For example, torture of women and girls in detention is often carried out in an intensely gendered manner. ${ }^{83}$ Similarly, the war crime of committing acts of terror may be carried out through various forms of rape, forced marriage/conjugal slavery and other gender-based prohibited acts. ${ }^{84}$ Forced displacement also has gender-specific effects: for example, the position of women and girls in society, their care responsibilities, or their frequent lack of means to travel, means that they may not be able to escape the violence as readily as more mobile citizens. ${ }^{85}$ Once they do flee, they tend to suffer immense hardship as they make their way to a refuge-they may be physically and sexually attacked, robbed or extorted along the way, ${ }^{86}$ and they often must search for basic necessities of life while caring for family members. ${ }^{87}$ Their journey to safety may also be fraught with other gender-related forms of harm, including paying for safe passage with sexual favours.

"The massive upheavals and social dislocation caused by conflict also have particular impacts on women, who bear the disproportionate burden of social and economic rights

\footnotetext{
${ }^{81}$ Institute of Human Rights Communication Nepal, 'Sexual Violence in the "People's War": The Impact of Armed Conflict on Women and Girls in Nepal,' 2006, cited in ICTJ, 'Across the Lines', note 43 above, 32 n. 39.

82 ICTJ, 'Across the Lines', supra note 43 at 32.

${ }^{83}$ Torture through rape was mentioned above; other forms include: inserting foreign objects such as guns, sticks or knives, into the vagina; walking on a women's body with heavy boots; punching and kicking sensitive areas such as breasts and genitals; applying electric shocks to breasts and genitals; forced nudity; and threats of sexual abuse: ibid.

84 Sesay Trial Judgment, note 48 above, paras. 131347-1356; Taylor Trial Judgment, note 80 above, paras. 20342037, 2051-2052, 2175 and 2177.

${ }^{85}$ UNHCR, Handbook on the Protection of Women and Girls, March 2008, available online at http://www.unhcr.org/protect/PROTECTION/47cfae612.html, 8 .

${ }^{86} \mathrm{HRW}$, 'Welcome to Kenya', note 67 above, 22.

${ }^{87}$ Human Rights Watch, 'Sexual Violence and its Consequences among Displaced Persons in Darfur and Chad', 12 April 2005, available online at http://www.hrw.org/reports/2005/04/12/sexual-violence-and-itsconsequences-among-displaced-persons-darfur-and-chad, 6; International Committee of the Red Cross, 'Women Facing War', 31 December 2001, available online at http://www.icrc.org/eng/resources/documents/publication/p0798.htm, 65 [ICRC, 'Women Facing War'], 6566.
} 
violations." 88 Conflict disrupts local economies, often preventing small female-run businesses from operating. ${ }^{89}$ Conflict also disrupts the ability of women and girls to provide food and other necessities for their families: this may be a deliberate tactic to cause starvation or other deprivation, or it may be a by-product of fighting. ${ }^{90}$ Conflict also presents opportunities for extortion and criminal activities, causing even more financial difficulties in female-headed households who are desperate to find means to support their families. ${ }^{91}$ As a result of conflict-created poverty, women and girls may be forced to sell their most valuable possessions or may undertake illegal activities or prostitution to gain access to survival goods. ${ }^{92}$ In polygamous societies, the economic hardships of conflict may force women into becoming a third or fourth wife. ${ }^{93}$

Forced evictions during conflict or generalized violence can have a serious impact upon women and girls. ${ }^{94}$ Often, the home represents the centre of life for family, and care for the individuals within the home is often the responsibility of women and girls. ${ }^{95}$ Loss of this centre of existence represents a loss of security and independence, as well as of possessions. ${ }^{96}$

Education is also affected by conflict, and has a specific impact on girls. For example, in Somalia, girls at school, or en route between home and school, are targeted for rape and forced marriage, which has resulted in girls leaving school-usually more quickly and at a much higher rate than boys. ${ }^{97}$ Sometimes girls are withdrawn from school to provide help at

${ }^{88}$ UN Women, '2011-2012 Progress of the World's Women: In Pursuit of Justice', available online at http://progress.unwomen.org/pdfs/EN-Report-Progress.pdf, 84 .

${ }^{89}$ ICTJ, 'Across the Lines', note 43 above, 43.

${ }^{90}$ ICRC, 'Women Facing War', note 87 above, 76-77, and Gardam and Jarvis, note 27 above, 40.

${ }^{91} \mathrm{HRW}$, 'At a Crossroads', note 51 above, 22-25.

${ }^{92}$ European Center for Constitutional and Human Rights, 'Study on Criminal Accountability in Sri Lanka as of January 2009', June 2010, available online at http://www.ecchr.de/index.php/ecchrpublications.html?file=tl files/Dokumente/Publikationen/ECCHR_Sri\%20Lanka\%20Study.pdf, 23; UNICEF, 'The Impact of Conflict on Women and Girls in West and Central Africa and the UNICEF Response', February 2005, available online at http://www.unicef.org/publications/index 25262.html, 21.

${ }_{93}$ M. Turshen, 'Women's War Stories', in M. Turshen and C. Twagiramariya, eds, What Women do in Wartime: Gender and Conflict in Africa (New York: Zed Books, 1998), 16.

${ }^{94}$ L. Farha, 'The Case of Forced Evictions', in I. L. Sajor, ed., 'Our Common Grounds', in Common Grounds, Violence Against Women in War and Armed Conflict Situations (Quezon City, Philippines: Asian Centre for Women's Human Rights, 1998), 77.

${ }_{95}$ Graça Machel, 'Impact of Armed Conflict on Children', 26 August 1996, UN Doc. A/51/306, cited in Gardam and Jarvis, note 27 above, 31.

96 B. Goldblatt and S. Meintjes, 'South African Women Demand the Truth' in M. Turshen and C. Twagiramariya, eds., What Women do in Wartime: Gender and Conflict in Africa (New York: Zed Books, 1998), 47.

${ }^{97}$ Human Rights Watch, 'No Place for Children: Child Recruitment, Forced Marriage and Attacks on Schools in Somalia', 10 February 2012, available online at http://www.hrw.org/reports/2012/02/20/no-place-children, 62-63 [HRW, ‘No Place for Children']. 
home, especially in the absence of menfolk or when their mothers are forced to leave home to find work. ${ }^{98}$ Other times girls are excluded from schools, most notably in Talibancontrolled areas of Afghanistan. ${ }^{99}$ Within schools, warring parties may deliberately attack female students and teachers. ${ }^{100}$

Women and girls are often actors in conflict, and are not only bystanders. ${ }^{101}$ They may be involved in activating, maintaining and perpetuating conflict. ${ }^{102}$ They may be fighters, political leaders or organizers, informants, lookouts or medical caregivers and/or they may protect others doing these tasks. ${ }^{103}$ They may also be involved in resolving conflict. Sometimes, these choices are relatively freely taken, but sometimes these choices are taken in severely constraining circumstances, such as poverty and extreme physical and psychological insecurity. ${ }^{104}$ Sometimes, there is no choice: for example, many girls have been abducted and forced to serve as child soldiers. ${ }^{105}$ All of these roles can put women and girls at risk for persecution both during the conflict and in the post-conflict period. ${ }^{106}$

The impact of conflict does not necessarily end when the conflict is considered over by the international community: "consistently across all conflicts, sexual and gender-based violence rarely conforms to the timelines of peace treaties and ceasefires but endures past them."107

\footnotetext{
${ }^{98}$ Women's Refugee Commission, 'Refugee Girls: The Invisible Faces of War', May 2009, available online at http://www.womensrefugeecommission.org/programs/youth/763-girlsstories , 16-17.

99 Oxfam, 'High Stakes: Girls' Education in Afghanistan', 24 February 2011, available online at http://www.oxfam.org/en/policy/high-stakes-girls-education-afghanistan, 15.

${ }^{100}$ UNICEF, 'Machel Study 10-Year Strategic Review: Children and Conflict in a Changing World', April 2009, available online at http://www.un.org/children/conflict/english/machel10.html, 22.

${ }^{101}$ E.g., in Nepal, women were a prominent and dynamic presence within the ranks of the Maoist movement and insurgency, and in this way were active within the conflict: ICTJ, 'Across the Lines', note 43 above, 26.

${ }^{102}$ Ní Aolaín et al., On the Frontlines, note 33 above, 42 and United Nations Secretary-General, Women, Peace and Security: Study Submitted by the Secretary-General Pursuant to Security Council Resolution 1325 (2000) (New York: United Nations, 2002), para. 48 [United Nations Secretary-General, Women, Peace and Security].

${ }^{103}$ ICRC, 'Women Facing War', note 87 above, 23; Ní Aolaín et al., On the Frontlines, note 33 above, 43 ; United Nations Secretary-General, Women, Peace and Security, note 102 above, paras. 47-48.

104 E.g., girls in Sri Lanka who were poor, lived in a conflict zone, and were separated from their family were more likely to join an armed group: Y. E. Keairns, The Voices of Girl Soldiers: Sri Lanka (New York: Quaker United Nations Office, 2003), 16. Other risk factors that were important in their becoming child soldiers were: dropping out of school; not having a voice in decisions that affect their life; being marginalized in new family structures; and the failure to be protected by the family: ibid.

${ }^{105}$ UN Division for the Advancement of Women and UNICEF Expert Group, 'The Girl Child and Armed Conflict: Recognizing and addressing grave violations of girls' human rights', 28 September 2006, UN Doc. EGM/DVGC/2006/EP.12, 4-6 and 9-10.

${ }^{106}$ E.g., see: 'Timor-Leste: Women are also resistance heroes', IRIN Humanitarian News and Analysis, 5 June 2012, available online at http://www.irinnews.org/Report/95583/TIMOR-LESTE-Women-are-also-resistance$\underline{\text { heroes }}$

${ }^{107}$ Ní Aolaín et al., On the Frontlines, note 33 above, 46.
} 
Violence against women and girls tends to become 'normalized' during conflict and carries into the post-conflict period. ${ }^{108}$ As well, some women and girls continue to live in conflictcreated social circumstances: for example, many girls (now women) who were forced to become 'bush wives' during the Sierra Leone conflict stayed with their 'husbands' after the conflict, as social stigmatization, loss of family, poverty, and loss of education left them with no other alternatives. ${ }^{109}$

This Part has outlined a number of ways in which conflict has profound and lasting effects on the lives of women and girls. The discussions in Parts 3 and 4 below will outline how some of these experiences have been recognized as creating a well-founded fear of persecution for reasons of race, religion, nationality, membership of a particular social group or political opinion. However, the discussion in Part 3 will also illustrate that, many times, the refugee claims of women and girls fleeing conflict are dismissed as stemming from indiscriminate violence - violence that is assumed to affect everyone similarly in a given conflict area.

\section{PERSECUTION}

The Refugee Convention requires that the refugee claimant possess a well-founded fear of a form of harm that qualifies as persecution. ${ }^{110}$ The term 'persecution' is not defined in the Convention, though there is agreement that "a threat to life or freedom on account of race, religion, nationality, political opinion or membership of a particular social group" and other serious violations of international human rights constitute persecution. ${ }^{111}$ There are a number of gender-related forms of harm that are currently considered to fit within these parameters - such as rape, dowry-related violence, female genital mutilation, domestic violence, and trafficking - because they inflict severe pain and suffering (both mental and physical), whether perpetrated by State or non-State actors. ${ }^{112}$ However, only some gender-

\footnotetext{
108 UN Women, note 88 above, 84.

${ }^{109}$ As such, sexual slavery is considered a continuing crime: Taylor Trial Judgment, note 80 above, paras. 119 and 1018.

${ }^{110}$ Refugee Convention, note 4 above, Art. 1A(2).

111 UNHCR, 'Handbook on Procedures and Criteria for Determining Refugee Status under the 1951 Convention and the 1967 Protocol Relating to the Status of Refugees', January 1992, HCR/1P/4/Eng/Rev.1, available online at http://www.unhcr.org/refworld/pdfid/3ae6b3314.pdf, para. 51. Such human rights would include those listed in the Convention on the Elimination of All Forms of Discrimination Against Women (entered into force 3 September 1981) 1249 UNTS 13.

112 UNHCR, 'Guidelines on International Protection No. 1: Gender-Related Persecution', note 8 above, para. 9.
} 
related forms of ill-treatment common in the context of conflict have been recognized as rising to the level of persecution.

This Part will begin by examining the conflict-related violation that is most well-established as a form of gendered persecution: rape. Despite the seeming solidity of this recognition, an examination of the case law demonstrates that there are still problem areas related to rape that have not yet been overcome in refugee jurisprudence. This Part then turns to examine case law on the recognition of other forms of conflict-related sexual, and non-sexual but still gendered, violence as persecution. This Part concludes by discussing how gender-related persecution is, or may be, overlooked when decision-makers consider conflict-related illtreatment to be indiscriminate in nature.

\section{Rape in Conflict}

Rape is committed for many reasons during conflict. ${ }^{113}$ These reasons may range from opportunistic "sexual looting", to strategic design, to a combination of the two. ${ }^{114}$ These reasons may overlap and co-exist in a given conflict, and may also change over time. Rape can also be committed in many ways, such as brutal gang rapes, the insertion of various objects into victims' genitalia, the raping of pregnant women and forced sexual intercourse between male and female civilian abductees, as had been carried out by the rebels during the conflict in Sierra Leone. ${ }^{115}$ Rape is an expression by the perpetrator of control and power, ${ }^{116}$ and therefore is effective in not only physically and psychologically harming the victims, but also in tearing apart social units (such as families and communities). ${ }^{117}$ This is why rape has been acknowledged as a particularly effective tool of genocide, ${ }^{118}$ as a crime against humanity (including the crime against humanity of persecution), ${ }^{119}$ and as a war crime. ${ }^{120}$ Rape has also been recognized as a human rights violation. ${ }^{121}$

\footnotetext{
113 For a review of reasons or motives behind conflict-related sexual violence, see: OCHA Policy Development and Studies Branch, 'Sexual Violence and Conflict: Understanding the Motivations', 20 June 2008, available online at http://ochaonline.un.org/OchaLinkClick.aspx?link=ocha\&docId=1092310.

${ }^{114}$ X. Agirre Aranburu, 'Sexual Violence Beyond Reasonable Doubt: Using Pattern Evidence and Analysis for International Cases' (2010) 23 Leiden Journal of International Law 609 at 613-614, 622.

115 Sesay Trial Judgment, note 48 above, paras. 1181, 1185, 1193-1194, 12-5-1207 and 1289.

${ }^{116}$ Eriksson, note 36 above, 171.

117 Ibid. 126; Sesay Trial Judgment, note 48 above, paras 1349-1350.

118 The International Criminal Tribunal for Rwanda has observed: "Sexual violence was an integral part of the process of destruction, specifically targeting Tutsi women and specifically contributing to their destruction and to the destruction of the Tutsi group as a whole": Akayesu Trial Judgment, note 66 above, para. 731.

${ }^{119}$ E.g., Prosecutor v. Krstić, Case No. IT-98-33-T, Judgment, 2 August 2001, paras. 617-618; and Prosecutor v. Brdjanin, Case No. IT-99-36-T, Judgment, 1 September 2004, para. 1008.
} 
Given the serious harm created by rape, it is therefore not surprising that rape has been identified within international and domestic refugee law as a form of persecution. UNHCR has stated that "[t]here is no doubt" that rape is an act which inflicts severe pain and suffering (both mental and physical) and which has been used as a form of persecution by States and non-State actors. ${ }^{122}$ Various country guidelines, directed at refugee claim adjudicators, also specify rape as a form of persecution. ${ }^{123}$ Domestic refugee case law has also recognized rape in conflict as a form of persecution: "it is not disputed that rape amounts to persecution". ${ }^{124}$ Within the case set, 20 cases involved claims of rape (of the claimant or a family member), or fear of rape, as persecution. ${ }^{125}$ Of these, eight claims or appeals were accepted on the evidence of past rape and/or future feared rape. ${ }^{126}$ For example, in a New Zealand case involving the Democratic Republic of the Congo (DRC), the female applicant's husband was sexually assaulted in detention; her mother and sister were raped during a

\footnotetext{
${ }^{120}$ Rape is explicitly listed as a crime against humanity, and sometimes also as a war crime, in international criminal statutes: e.g. Rome Statute, note 34 above, Arts. 7(g). 8(2)(b)(xxii) and 8(2)(e)(vi); Statute of the International Criminal Tribunal for the Former Yugoslavia (adopted 25 May 1993) 32 ILM 1192, Art. 5(g); Statute of the International Criminal Tribunal for Rwanda (adopted 8 November 1994) 33 ILM 1602, Art. 3(g); Statute of the Special Court for Sierra Leone (adopted 14 August 2000) 40 ILM 247, Art. 2(g); and Allied Control Council Law No 10, "Punishment of Persons Guilty of War Crimes, Crimes Against Peace and Against Humanity", 20 December 1945, Official Gazette of the Control Council for Germany, No. 3, Art. 2(a) at 50-55 (entered into force 31 January 1946).

${ }^{121}$ UN Declaration on the Elimination of Violence Against Women, UNGA Res. 48/104, 20 December 1993, 217, Art. 2.

122 UNHCR, ‘Guidelines on International Protection No. 1: Gender-Related Persecution', note 8 above, para. 9.

${ }^{123}$ E.g., Canadian Guidelines, note 12 above, para. B; US Guidelines, note 17 above, 9; and UK Guidelines, note 16 above, 2A.18.

124 SS (Burundi) CG [2004] UKIAT 00290 (29 October 2004) (UK), para. 16 [SS (UK)].

1251203764 [2012] RRTA 312 (18 May 2012) (Australia) [1203764 (Australia)]; TA6-00022 [2007] RPDD No. 233 (29 October 2007) (Canada) [TA6-00022 (Canada)]; JXV (Re) [2008] RPDD No. 3 (23 January 2008) (Canada) [JXV (Canada)]; VA8-01482 [2010] RPDD No. 105 (8 March 2010) (Canada) [VA8-01482 (Canada)]; VA9-00148 [2010] RPDD No. 512 (30 June 2010) (Canada) [VA9-00148 (Canada)]; MA8-07482 [2010] RPDD No. 145 (17 September 2010) (Canada) [MA8-07482 (Canada)]; Kika v Minister of Citizenship and Immigration [2011] FC 1039 (2 September 2011) (Canada) [Kika (Canada)]; Refugee Appeal Nos. 73894, 73895, 73896, 73897 (24 January 2005) (New Zealand) [73894 et al. (New Zealand)]; Refugee Appeal No. 76464 \& 76465 (28 June 2010) (New Zealand) [76464 \& 76465 (New Zealand)]; $A B$ [2011] NZIPT 800019 (24 August 2011) (New Zealand) [ $A B$ (New Zealand)]; SS (UK), note 124 above; NS Afghanistan CG [2004] UKIAT 00328 (30 December 2004) (UK) [NS (UK)]; In re B (FC) (Appellant) (2002) Regina v. Special Adjudicator (Respondent) ex parte Hoxha (FC) (Appellant) [2005] UKHL 19 (10 March 2005) (UK) [In re B (FC) (UK)]; BK DRC CG [2007] UKAIT 00098 (September 2007) (UK) [BK (UK)]; LM Republic of Congo (Congo-Brazzaville) CG [2008] UKAIT 00064 (14 August 2008) (UK) [LM Congo (UK)]; PS (Sri Lanka) v Secretary of State for the Home Department [2008] EWCA Civ 1213 (23 October 2008) (UK) [PS (UK)]; AMM and others Somalia CG [2011] UKUT 00445 (IAC) (15 July 2011) (UK) [AMM and Others (UK)]; Mohammed v Attorney General [2005] 400 F.3d 785 (10 March 2005) (US) [Mohammed (US)]; Mambwe v Attorney General [2009] 572 F.3d 540 (16 July 2009) (US) [Mambwe (US)]; and Kante $v$ Attorney General [2011] FED App. 0014N (6 ${ }^{\text {th }}$ Cir.) (7 January 2011) (US) [Kante (US)].

${ }^{126}$ Kika (Canada), 73894 et al. (New Zealand); $A B$ (New Zealand); NS (UK); In re B (FC) (UK); LM Congo (UK); PS (UK); and AMM and Others (UK); all note 125 above.
} 
visit to their house by soldiers and other women in her house were sexually assaulted: this and other treatment during conflict was considered to amount to a well-founded fear of persecution. ${ }^{127}$

However, it must be noted that several of the eight positive decisions presented troubling histories, only remedied on appeal. For example, in the Canadian case of Kika, the claimant had been raped by soldiers in the DRC in 2006. ${ }^{128}$ Her claim was initially denied on the basis of lack of evidence of persecution but was ordered to be reassessed, as "the officer apparently did not consider the possibility that Ms. Kika had a gender-based claim for refugee protection as a result of her sexual assault in 2006." 129 As in Kika, the claimant in the United Kingdom (UK) case of NS (Afghanistan) was originally denied asylum, in part because the adjudicator had found that her rape occurred "because the assailant found her attractive, and therefore that the attack was a purely personal one, and no more than a common crime". ${ }^{130}$ On appeal, the Immigration Appeal Tribunal stated that this "finding was not based on the evidence before [the adjudicator]". ${ }^{131}$ The evidence was that the applicant's husband had been detained by the militia of a warlord on suspicion of supporting the warlord's enemy. ${ }^{132}$ The warlord's nephew took advantage of her husband's detention and the applicant's vulnerability ${ }^{133}$ and demanded that the applicant become his fourth wife; when she refused, he raped, beat and threatened her with death. ${ }^{134}$ The Tribunal concluded that "to take as a wife, by force, the wife of one's enemy, after first imprisoning him, is not an uncommon act in the course of war or other conflict, as an act of aggression against the enemy." 135 The applicant was granted refugee status. ${ }^{136}$

In another UK case from the case set, PS (Sri Lanka), the applicant, a Tamil woman from Jaffna, had been raped on three occasions in her home by Sri Lankan soldiers. ${ }^{137}$ The first

\footnotetext{
12773894 et al. (New Zealand), note 125 above, paras. 35, 43 and 97 [it was unclear whether the applicant herself had been raped].

${ }^{128}$ Kika (Canada), note 125 above, para. 5.

129 Ibid., para. 14.

${ }^{130}$ NS (UK), note 125 above, para. 16. Similarly, in Mambwe (US), the applicant was asked whether it was possible that the UNITA soldiers who had raped her were merely pursuing their own gratification. She agreed, but it is likely that she neither understood the implication of agreeing nor had considered the various possible motivations, note 125 above, 4 .

${ }^{131}$ NS (UK), note 125 above, para. 16.

132 Ibid., para. 28.

${ }^{133}$ Ibid., para. 29 (she was still being harassed by the militia, who killed her sister).

${ }^{134}$ Ibid., paras. 31 and 68.

135 Ibid., para. 69.

136 Ibid., para. 101.

${ }^{137}$ PS (UK), note 125 above, para. 1.
} 
time, she was raped by two soldiers. ${ }^{138}$ Five days later, one of those soldiers returned, accompanied by a different soldier, and both of them raped her. A week or so after, these latter two soldiers returned, held her father at gunpoint so he would witness the act, and raped her again. ${ }^{139}$ She subsequently tried to kill herself and failed, and then discovered that she was pregnant. ${ }^{140}$ The immigration judge classified these soldiers as "rogue", comparing them to three civilian criminals, and concluded that these past rapes had no relevance to the potential for future persecution. ${ }^{141}$ This decision was rejected on appeal: the soldiers were clearly able to act with impunity, given the repetition of the rapes, and therefore there was a real risk that she would again be targeted for rape by Sri Lankan soldiers in the vicinity. ${ }^{142}$ In a similar decision, the UK case of LM (Republic of Congo) accepted, on appeal, that the applicant had been raped in 1997 and that she had "a real risk of something similar happening to her on return", although that latter contention had not been accepted earlier. ${ }^{143}$ Finally, in In re B (FC), the House of Lords considered an appeal by a female Kosovar Albanian applicant who had been raped in front of her husband, sons and 20-30 neighbours due to suspected involvement in the Kosovo Liberation Army. Baroness Hale of Richmond found that the Court of Appeal had failed to realize that "the persecution of Mrs. B was expressed in a different way from the persecution of her husband and sons", through rape, and that rape may be a weapon or strategy of war. ${ }^{144}$

These examples demonstrate that rape claims stemming from conflict face some common obstacles. The first obstacle is in the characterization of the rape. Some adjudicators - such as the initial adjudicator in NS (Afghanistan) - view sexual violence in conflict as a matter of personal sexual gratification, rather than as a method of terrorizing, controlling or punishing civilians. ${ }^{145}$ In the UK case of Najjemba, the court held that a woman from Northern Uganda who had suffered rape at the hands of government soldiers was the victim of "simple and dreadful lust" and not persecution. ${ }^{146}$ This was despite her connection to her son, who was suspected of connection to a rebel group opposed to the Ugandan government, who had been 'disappeared'. ${ }^{147}$

\footnotetext{
138 Ibid.

139 Ibid.

140 Ibid.

${ }^{141}$ Ibid., para. 7.

142 Ibid., paras. 15 and 16.

${ }^{143}$ LM Congo (UK), note 125 above, paras. 1, 2 and 114.

${ }^{144}$ In re $B(F C)(\mathrm{UK})$, note 125 above, para. 30.

${ }^{145}$ NS (UK), note 125 above, para. 16.

${ }^{146}$ Najjemba $v$. Secretary of State for the Home Department [2002] EWCA Civ 1082, para. 9 (15 July 2002) (UK).

147 Ibid., para. 2.
} 
A related concern is that those who commit sexual violence in conflict are sometimes viewed by adjudicators as having committed the act in their private capacity and are therefore analogous to common criminals rather than persecutors, which was the original reasoning in PS (Sri Lanka) and the reasoning in the Canadian case of VA9-00148. ${ }^{148}$ Both the 'conflict rape as lust' and the 'conflict rape as a common crime' approaches demonstrate a profound misunderstanding of the context of rape in conflict. As Macklin puts it: "some decisionmakers have proven unable to grasp the nature of rape by State actors [and non-State fighters, too] as an integral and tactical part of the arsenal of weapons deployed to brutalise, dehumanise, and humiliate women and demoralise their kin and community." ${ }^{149}$ The characterization of rape as lust incorrectly creates the impression that sexuality, rather than an exercise of power and gender-based discrimination, is at play. It also completely ignores the coercion, overarching violence and impunity created by the conflict. In other words, even if the perpetrator's motive happens to be entirely sexual, it does not follow that the perpetrator did not target the victim for persecutory reasons or that his conduct does not cause severe pain and suffering. ${ }^{150}$ Similarly, the characterization of rape as a 'common' criminal activity instead of persecution assumes that the rape in conflict is somehow random or private - and therefore unconnected to the State and lacks the discriminatory or rightsviolating character required by the refugee definition. ${ }^{151}$ This is despite the fact that the rape occurs in the context of overarching violence and impunity enhanced by vulnerability and gender-based discrimination. [Note that the issue of rape as part of untargeted indiscriminate violence is discussed below.] Both types of (mis)characterizations of rape are not exclusive to refugee claims involving conflict, ${ }^{152}$ but the fact that they occur means that decision-makers are failing to adequately consider the environment surrounding the rape.

\footnotetext{
148 PS (UK), note 125 above, at para. 7; VA9-00148 (Canada), note 125 above, para. 16. More generally, see H. Crawley and T. Lester, 'Comparative Analysis of Gender-Related Persecution in National Asylum Legislation and Practice in Europe', May 2004, EPAU/2004/05, available online at http://www.unhcr.org/40c071354.pdf, para. 167; and Crawley, Refugees and Gender, note 21 above, 89. See also $N$ v. UK [2005] UKHL 31 (5 May 2005) (UK), para. 57 [N (UK)], relating that the adjudicator has found that the applicant's rape by government soldiers as part of her interrogation for being part of the LRA was committed by "rogue elements in the security force".

${ }^{149}$ A. Macklin, 'Refugee Women and the Imperative of Categories' (1995) 17 Human Rights Quarterly 213, 226.

150 Prosecutor v. Rukundo, Case No. ICTR-2001-70-A, Appeals Judgment, 20 October 2010, Pocar J. partial dissent, para. 11.

151 T. Spijkerboer, Gender and Refugee Status (Burlington, VT: Ashgate Publishing, 2000), 94-95 and 97-98. The assumption that rape is 'private' can lead to three incorrect assumptions: first, a denial that the rape amounts to persecution; second, that it is not linked to the conflict; and third, that it has no state connection: Crawley, Refugees and Gender, note 21 above, 89.

${ }^{152}$ Crawley, Refugees and Gender, note 21 above, 44.
} 
On a positive note, these characterizations were correctly dismissed in In re B (FC) and the UK case of $N .{ }^{153}$

The second common obstacle identified in the case set is that, sometimes, adjudicators (and the applicant's counsel) do not recognize the importance of considering the after-effects of past rape in order to consider the risk of future persecution. ${ }^{154}$ These after-effects commonly include societal stigma, which considers raped women and girls to be somehow 'tainted'. ${ }^{155}$ This stigma is a form of discrimination, and it can create social, cultural and economic exclusion for the victim and her children, and lead to increased vulnerability to sexual and other forms of violence, as well as death. ${ }^{156}$ For example, the U.S. case of Mambwe considered the claim of a young Angolan woman who had fled from UNITA forces as a child, was raped in a Zambian refugee camp (and gave birth as a result), and was kidnapped from Zambia by UNITA and repeatedly raped. ${ }^{157}$ Her appeal was denied on the basis that the conflict in Angola had ended. ${ }^{158}$ However, it appears that the Court (and earlier decisionmakers) did not consider the lasting stigma (and therefore discrimination) she would likely face in post-conflict Angola as a lone young women with no relatives, who had been a past victim of rape by rebels, raising a child conceived through rape. ${ }^{159}$ On the other hand, in In re $B$ (FC), Baroness Hale of Richmond states: "To suffer the insult and indignity of being regarded by one's own community (in Mrs. B's words) as 'dirty like contaminated' because one has suffered the gross ill-treatment of a particularly brutal and dehumanizing rape directed against that very community is the sort of cumulative denial of human dignity

${ }^{153}$ In re $B(F C)(\mathrm{UK})$, note 125 above, para. 30; and $N(\mathrm{UK})$, note 148 above, para. 58.

${ }^{154}$ E.g., even though NS (UK) contains strong gender analysis, the Immigration Appeal Tribunal did not consider the specific future risk of further victimization (including stigmatization) raised by the applicant's previous rape. However, it did consider the risk to the applicant and her children of living in Kabul on her own without family or community support: NS (UK), note 125 above, paras. 64-65, 93-94 and 96. See also JXV (Canada), note 125 above, paras. 77 and 91: the applicant, who was from Bosnia-Herzegovina, claimed that she had been raped by Serb soldiers during the conflict and this would make her an outcast in her country of origin. The adjudicator did not consider this aspect and instead focused on another part of her claim (on religious persecution).

${ }^{155}$ E.g., in societies where virginity is highly valued, "loss of virginity for women often means loss of marriage opportunities, which can have severe social-cultural repercussions for them and their families." ICTJ, 'Across the Lines', note 43 above, 27.

${ }^{156}$ Crawley, Refugees and Gender, note 21 above, 43.

${ }^{157}$ Mambwe (US), note 125 above, 2.

158 Ibid., 7.

${ }^{159}$ Rape victims with children are often severely stigmatized and ostracized (as are their children): Turshen, note 93 above, 16. See also ICTJ, Across the Lines, note 43 above, 34. In some societies, the stigma seriously affects the child, as well: for example, In Nepal, children born of rape are not permitted to be registered, and therefore these children may not be able to obtain a citizenship card - this represents a sort of 'civil death' for the child: ibid., 34 . 
which to my mind is quite capable of amounting to persecution" as "the victim is punished again and again for something which was not only not her fault but was deliberately persecutory of her, her family and her community." ${ }^{160}$ She did note, however, that these "issues were not fully explored at an earlier stage in the proceedings" 161 - these issues should have been identified by earlier decision-makers, but were overlooked. An evaluation of the risk created by the after-effects of rape should be a standard consideration in conflict-related cases, in order to better understand potential sources of future persecution.

Other common obstacles to conflict-related refugee claims based on rape - such as rape being considered to be part of indiscriminate conflict, rape being found not to relate to a Convention ground, rape evidence being considered as not credible, and a lack of relevant country of origin information on rape in conflict - will be dealt with in the sections below.

\section{OTHER Forms of SEXUAL VIOLENCE IN CONFLICT}

While case law and academic analysis to date has largely focused on rape as a form of persecution common in conflict, other conflict-related sexual violence can also amount to persecution. International, regional and domestic refugee law have provided that other forms of sexual violence (whether committed in conflict or in peacetime), apart from rape, may qualify as forms of persecution. ${ }^{162}$ International criminal law provides some assistance in enumerating examples of such sexual violence: sexual slavery (including sexual slavery resulting from trafficking), enforced prostitution, mutilation of sexual organs or breasts and forced nudity have all been recognized as forms of sexual violence amounting to crimes against humanity and/or war crimes. ${ }^{163}$ There is also international guidance and domestic

${ }^{160}$ In re $B(F C)(\mathrm{UK})$, note 125 above, para. 36.

161 Ibid., para. 39.

162 E.g., trafficking for sexual slavery or enforced prostitution: UNHCR, 'Guidelines on International Protection: The Application of Article 1(A)(2) of the 1951 Convention and/or 1967 Protocol related to the Status of Refugees to Victims of Trafficking and Persons at Risk of Being Trafficked', 7 April 2006, HCR/GIP/06/07, available online at http://www.unhcr.org/443b626b2.html, para. 15 [UNHCR, 'Trafficking Guidelines']; Council Directive (EC) No. 2004/83/EC of 29 April 2004 on the minimum standards for qualification and status of third country nationals or stateless persons as refugees or as persons who otherwise need international protection and the content of the protection granted [2004] OJ L304, Art. 9.2(a) includes acts of sexual violence; and UK Guidelines, note 16 above, para. 2A.18, which lists, apart from rape, "enforced nakedness, mechanical or manual stimulation of the erogenous zones; the insertion of objects into the body openings; the forced witnessing or commission of sexual acts; forced masturbation; fellatio and oral coitus; a general atmosphere of sexual aggression, the loss of the ability to reproduce plus threats of the above."

${ }^{163}$ E.g., Rome Statute, note 34 above, Arts. 7(g), 8(2)(b)(xxii) and 8(2)(e)(vi); Sesay Trial Judgment, note 48 above, paras. 677-687, 1205 and 1208; Prosecutor v. Tadić, Case No. IT-94-1-T, Opinion and Judgment, 7 May 1997, paras 45, 198, 206; Akayesu Trial Judgment, note 66 above, para. 697; Munyaneza, note 63 above, para. 96. 
case law relating to trafficking for the purposes of sexual slavery or enforced prostitution. ${ }^{164}$ Given their comparability to rape, it can be expected that the same obstacles outlined above would apply to other forms of sexual violence. ${ }^{165}$

\section{Other Forms of Gender-Related Ill-Treatment in Conflict}

There are a number of gender-related forms of ill-treatment that occur in conflict that may qualify as persecution. These include conjugal slavery (also referred to as 'forced marriage' in conflict), ${ }^{166}$ forced pregnancy, ${ }^{167}$ forced sterilization ${ }^{168}$ and forced abortion/miscarriage. ${ }^{169}$ The latter three violations are likely the easiest to understand as gender-related crimes, since they are targeted at female reproductive organs. Conjugal slavery, which is comprised of sexual slavery plus domestic slavery, is also clearly a gender-related crime: the perpetrators enforce a norm of 'femaleness' on the victims, expecting them to submit to sex, cook and clean on demand.

Other forms of gender-related persecution in conflict may be more difficult to identify, for two reasons: first, the persecutory acts may look gender-neutral on their face even though they are in fact gendered and, second, women and girls may experience, and therefore identify, harms differently than do men and boys. Both reasons require all those working with refugee claimants to listen closely to the stories told, to consider whether what is said reveals potential gendered ill-treatment, and to ask appropriate questions to gain further insight. ${ }^{170}$ Applicants may describe seemingly gender-neutral forms of ill-treatment, such as torture, enslavement, starvation and imprisonment, but underneath those descriptions may lie a gendered form of the harm: torture through threatened or actual sexual touching or

\footnotetext{
${ }^{164}$ UNHCR, 'Trafficking Guidelines', note 162 above, para. 15; see also AM and BM (Trafficked women) Albania v. Secretary of State for the Home Department, CG [2010] UKUT 80 (IAC) (UK). This author has not located a conflict-specific trafficking asylum claim.

${ }^{165}$ On the stigmatization of trafficking victims, see UNHCR, 'Trafficking Guidelines', note 162 above, para. 18.

166 Taylor Trial Judgment, note 80 above, paras. 427-428; and Sesay Trial Judgment, note 48 above, paras. See also see: NS (UK), note 125 above, para. 69.

${ }^{167}$ Rome Statute, note 34 above, Arts. 7(g), 8(2)(b)(xxii) and 8(2)(e)(vi).

168 Ibid.

${ }_{169}$ M. Deen, 'Pregnant Girls Forced to Abort', The Lubanga Trial, 18 March 2009, available online at http://www.lubangatrial.org [Dean, Pregnant Girls']. The case of NS (UK), note 125 above, contained facts linked to attempted forced marriage: para. 31, and the case of Mambwe, note 125 above, contained facts related to pregnancy resulting from rape: 2 .

170 This has been referred to as 'hearing the right gaps' in order to pursue those gaps: H. Baillot, S. Cowan and V. Munro, "Hearing the Right Gaps': Enabling and Responding to Disclosures of Sexual Violence within the UK Asylum Process' (2012) Social and Legal Studies 1-28 [Baillot et al., 'Gaps']. Proper listening requires training: UNHCR, 'Improving Asylum Procedures - Gender', note 19 above, 10.
} 
rape ${ }^{171}$ enslavement by forced domestic labour, ${ }^{172}$ starvation through intentional restriction of women's movements such that they cannot tend to their fields/gardens or attend market (if those are traditionally 'female' roles in a given society), and imprisonment in apartments by the opposing side in a conflict, so as to create easily available female 'entertainment' for troops. ${ }^{173}$ Another example is terrorizing civilians: this may be achieved through a variety of methods, including rape, sexual slavery and conjugal slavery. ${ }^{174}$ In other words, while some ill-treatment will be gender-related on its face (like rape), other ill-treatment may only be revealed as such after gathering further information from the applicant. In the case set, there appeared to be missed chances to discover potential gendered ill-treatment, when illtreatment was simply described as 'torture' or 'beatings' without further explanation of how the torture or beatings were carried out. ${ }^{175}$

The way in which women view harm may be gender-differentiated: "preliminary empirical research suggests that loss of a child, separation from children, and witnessing harm to children or family members are particularly viewed by women as primary harms to the self, often as or more egregious than a severe violation of their own bodies." ${ }^{176}$ In addition, they may not be able to easily compartmentalize the harms they face into conflict- and nonconflict-related for the purposes of describing persecution, because of the way in which gender-related physical harms are interrelated with social and economic harms. ${ }^{177}$ For example, physical harms to the body are more easily understood as persecutory, but the insecurity or ill health caused by rape may be interlinked with the inability to collect wood for stoves or to plant crops, and both of the latter are also perceived by the victim as part of the persecution. ${ }^{178}$ In this way, both the physical harms and the economic harms are gendered. On a related note, it is important to realize that sexual violence is very rarely the sole or central part of a woman or girl's claim. ${ }^{179}$ Thus, applicants should be given the opportunity to identify the full range of conflict-related harms from her perspective, in order

\footnotetext{
${ }_{171}$ Prosecutor v. Furundžija, Case No. IT-95-17/1-T, Trial Judgment, 10 December 1998, para. 163.

172 Taylor Trial Judgment, note 81 above, paras. 1066, 1072-1075, 1094, 1098, 1108, 1144-1146, 1828 and 1833.

${ }^{173}$ Kunarac Trial Judgment, note 79 above, paras. 767-769, 772.

174 Sesay Trial Judgment, note 48 above, paras.1347-1351; and Taylor Trial Judgment, note 80 above, paras. 2034, 2036, 2037, 2051-2052, 2175 and 2177.

175 See 73894 et al. (New Zealand), note 125 above, para. 41; and EB (Ethiopia) v Secretary of State for the Home Department [2007] EWCA Civ 809 (31 July 2007) (UK) 1 [EB (UK)].

${ }^{176}$ Ní Aolaín et al., On the Frontlines, note 33 above, 48 and 154. This is illustrated in the observation that "[f]emale claimants may also fail to relate questions about "torture" to the types of harm which they fear": UNHCR, 'Guidelines on International Protection No. 1 - Gender-Related Persecution', note 8 above, para. 36(vii).

177 Ní Aolaín et al., On the Frontlines, note 33 above, 46.

${ }^{178}$ Example taken from ibid., 45.

${ }^{179}$ Baillot et al, 'Gaps', note 170 above, 21.
} 
for the harms to be evaluated cumulatively as persecution. In the case set, adjudicators tended to focus on the most obvious individual gender-related violation when considering whether persecution is gender-related, ${ }^{180}$ rather than evaluating the harms as a whole, although there were exceptions. ${ }^{181}$ As well, sometimes gender aspects were simply never raised or examined by the applicant (or her representative) or the decision-makers, or the adjudicator decided to focus on the non-gender-related aspects of the claim. ${ }^{182}$ This has been identified as a particular problem in cases involving sexual violence - "a tendency among some asylum professionals to marginalize, trivialize or ignore accounts of rape."183

\section{INDISCRIMINATE VERSUS TARGETED GENDER-RELATED ILL-TREATMENT}

This Part concludes by discussing a common way in which gender-related persecution is, or may be, overlooked when addressing claims of women and girls fleeing conflict situations: gender-related violence may be classified as part of the general indiscriminate consequences of conflict and not targeted at the claimant. This classification occurred in a significant number of the cases in the case set - this is obviously a major obstacle for female refugee claimants fleeing conflict. ${ }^{184}$ For example, in the Canadian case of VA9-00148, an applicant from the DRC described an attack in 2008, in which rebels came to her home, demanding money, since they knew that her family had a business. ${ }^{185}$ Her family was beaten and

${ }^{180}$ E.g., SS (UK), note 124 above; HH E Others Somalia CG [2008] UKAIT 00022 (November 2007) (UK) [HH (UK)]; LM Congo (UK), note 125 above; Mohammed (US), note 125 above; and Mambwe (US), note 125 above.

${ }^{181}$ E.g. NS (UK), note 125 above, paras. 60-64; and NA Iraq CG [2008] UKAIT 00046 (2 January 2008) (UK), paras. 91-98 [NA (UK)].

182 E.g. In re B (FC) (UK), note 125 above, paras. 30-39; $N$ (UK), note 148 above, para. 58; JXV (Canada), note 125 above, para. 91; 0901064 [2009] RRTA 373 (4 May 2009) (Australia) [0901064 (Australia)] (unclear whether her torture was gendered despite country of origin information on gendered abuse in detention (at para. 54), and whether she was chosen to deliver the parcels because of gendered assumption that a woman would attract less attention or would be less at risk; 1010754 [2011] RRTA 320 (4 May 2011) (Australia) (the gendered aspects of the applicant's status as a widow and of the harassment (para. 30) were not explored) [1010754 (Australia)]; and EB (UK), note 175 above (the potentially gendered aspects of torture were not explored); $A B$ [2011] NZIPT 800019 (24 August 2011) (New Zealand) paras. 6, 7, 14 and 62-64 [AB (New Zealand)]; and 73894 et al. (New Zealand), note 125 above, paras. 35, 43 and 97-104.

${ }^{183}$ Baillot et. al. 'Gaps', note 170 above, 2 and 21-22. See also $N(\mathrm{UK})$, note 148 above, para. 57, in which the only issue considered was whether the Appellant would be able to access treatment for HIV, but not the fact that she had been kidnapped by the Lord's Resistance Army and then raped by government soldiers.

1841002652 [2010] RRTA 557 (15 July 2010) (Australia) para. 68 [1002652 (Australia)]; TA8-00963 [2009] RPDD No. 395 (22 September 2009) (Canada), para. 7 [TA8-00963 (Canada)]; TA8-18792 [2010] RPDD No. 374 (17 June 2010) (Canada), para. 36 [TA8-18792 (Canada)]; VA9-00148 (Canada), note 125 above, para. 20; Kika (Canada), note 125 above, para. 9; PS (UK), note 125 above, para. 7; Camara v Attorney General [2009] 580 F.3d 196 (4 September 2009) (US), 8 [Camara (US)]; SS (UK), note 125 above, 16; and Gomez v. Immigration and Naturalization Service, 947 F.d 660; 1991 U.S. App. LEXIS 25697 (28 October 1991) (US), 664 [Gomez (US)]. ${ }^{185}$ VA9-00148 (Canada), note 125 above, para. 10. 
tortured, and the applicant was raped. ${ }^{186}$ The rebels stole $\$ 40,000$ and took her husband and step-son - she has not seen them since. ${ }^{187}$ The rebel violence subsequently increased, and her neighbor and her children were beheaded, while others had body parts amputated or were killed. ${ }^{188}$ While the adjudicator found that a nexus to a Convention ground does exist due to the sexual violence, he characterized the beatings, rape and torture of her and her family as "localized crime" and, even if the rebels had targeted them, it was for money and not for any other reason. ${ }^{189}$ This led to a decision that, "[a]lthough conditions in the DRC certainly involve a degree of risk and violence", the applicant and her family would not face a personalized risk to their lives if returned. ${ }^{190}$ This decision is particularly striking in that it lacks any consideration of the significant political and ethnic dimensions of the conflict in the DRC, including the political and ethnic choices by the various rebel groups of where, how and who they attack. ${ }^{191}$ As Goodwin-Gill and McAdam note: "A closer look at the background to the conflict ... and the ways in which it was fought, will often establish a link to the [Refugee] Convention." ${ }^{192}$

The classification of gender-related ill-treatment in conflict as indiscriminate leads to the assumption that the applicant was not personally targeted for past persecution, and/or that she can be returned to her country of origin because any future risk she would face is a risk faced by everyone in that country. While the facts of every case are individual, these underlying assumptions can legitimately be questioned. On the issue of personal targeting, it is crucial that decision-makers examine both the narrow and the wider context in which the violations occurred. In the case of VA9-00148 outlined above, the narrow focus reveals a potential case of targeting: the applicant was raped during the rebel attack, while her husband and son were abducted. ${ }^{193}$ Both forms of mistreatment are gendered: the applicant may have been targeted for rape because she was female, ${ }^{194}$ while the men may have been

\footnotetext{
186 Ibid.

187 Ibid.

188 Ibid.

189 Ibid., paras. 15 and 16.

190 Ibid., para. 20.

191 There are numerous reports by international and nongovernmental organizations detailing varying political and ethnic reasons for militia violence. For example, on motives for sexual violence by the Mai Mai, see: J. Kelly, "Rape in War: Motives of Militia in DRC" (June 2010, United States Institute of Peace) at http://www.usip.org/files/resources/SR243Kelly.pdf. The adjudicator did not appear to refer to any country of origin information in making this decision.

192 G.S. Goodwin-Gill and J. McAdam, The Refugee in International Law (New York: Oxford University Press, $3^{\text {rd }}$ ed., 2007), 126 [Goodwin-Gill and McAdam, The Refugee].

${ }^{193}$ VA9-00148 (Canada), note 125 above, para. 10.

194 There are many layers to this: she may have been targeted for rape because she is of the female sex (and therefore has the genitalia to rape); because of her gender (for example, due to patriarchal assumptions by the perpetrators that women are there to serve the needs of men); to punish her in a psychological and
} 
targeted for abduction because they are men (perhaps to become forced fighters). As well, if one examined the wider context of militia movements in the area in the applicant's area at the time of the attack, ${ }^{195}$ one might be able to discern other cross-cutting ways in which the applicant and her family were targeted - perhaps due to the (presumed) ethnicity or (presumed) political affiliation of the individuals in that area. These narrow and wider inquiries into the conflict would also inform analysis of the risk of future targeting for gender-related persecution (including persecution of a different type than originally suffered). ${ }^{196}$ These deeper inquiries - both gender-sensitive and intersectional - are crucial to more accurately determining whether violence is indiscriminate or targeted.

\section{LESSONS LEARNED}

During war, gender norms often take on even greater socio-political significance than during peacetime: for example, "the role of women in the biological and social reproduction of group identity places them in a position of particular vulnerability." 197 Thus, gender-related acts in conflict, such as the rape of women and girls, often take on deeper meanings or have broader repercussions (for families, for communities), thereby creating differentiated experiences. However, the significance of these meanings or repercussions "are currently rarely recognized in the asylum determination process." 198 This is evidenced by the common obstacles faced by women and girls in proving that they were persecuted in gender-related ways in the past and/or that they risk gender-related persecution in the future. Within rape claims, there are continuing difficulties with the incorrect characterization of rape in conflict as a 'private' act. As well, not enough attention is paid to the after-effects of past rape in creating future risks of persecution. While the case set did not shed much light on other types of ill-treatment that might be considered as gender-related persecution, international refugee and criminal law do provide some guidance - for example, identifying sexual slavery. Yet, there are many more forms, because seemingly gender-neutral persecutory acts can be carried out through gendered means or have gender-specific effects. This requires refugee decision-makers to listen carefully for, and draw out, gender-related ill-treatment,

physical manner without the use of physical weapons; to humiliate her male family members (that they cannot protect her, that the enemy has power); and/or to humiliate her community.

195 This requires detailed country of origin information. For more on this, see Part 6.1 below.

${ }^{196}$ E.g., AA (Uganda) v Secretary of State for the Home Department [2008] EWCA Civ 579 (22 May 2008) (UK), 4 $[A A(\mathrm{UK})]$, in which in humanitarian protection (but not refugee status) was granted to the applicant based on a future risk that the applicant (originally from Northern Uganda and a victim of rape) would be forced into prostitution if returned to Kampala: "Even if it is the fate of many of her countrywomen, I cannot think that either the AIT or the House of Lords that decided AH(Sudan) would have felt able to regard enforced prostitution as coming within the category of normal country conditions that the refugee must be expected to put up with."

${ }^{197}$ Crawley, Refugees and Gender, note 21 above, 88.

198 Ibid. This comment is from 2001, but the analysis in this Part demonstrates that it is still applicable. 
while at the same time respecting that women may identify harm in gender-differentiated ways. Unfortunately, the case set suggests that this careful listening is not always happening. Another, rather significant, obstacle is that a number of decision-makers classify genderrelated violence as part of the general indiscriminate consequences of conflict. It appears that this is done without necessarily considering potential gender-related reasons for targeting (for example, the various ways in which rape is used as a weapon of war) or the wider political and other dimensions of the conflict. If this contextual and gender-sensitive analysis is done, it is suggested that fewer cases of gender-related ill-treatment would be categorized as untargeted. ${ }^{199}$

\section{CONVENTION GROUNDS}

Under the Refugee Convention, only those who can demonstrate "well-founded fear of being persecuted for reasons of race, religion, nationality, membership of a particular social group or political opinion" can qualify as refugees. ${ }^{200}$ As gender is not explicitly listed as a persecutory ground, women and girls fleeing conflict for gender-related reasons must fit their claims within one of the other grounds. ${ }^{201}$ There are many different ways in which gender relates to the Convention grounds. If the persecutor would not have persecuted the victim had the victim not been female, "then an inference may be drawn that one of the motivations for persecution was the victim's gender." ${ }^{202}$ For example, a party to a conflict may impose specific forms of conformity on women and girls based on a particular ideological view of how they should act. ${ }^{203}$ When the reason underlying the persecution is the victim's gender, then "membership of a particular social group" may be the best

\footnotetext{
199 This does not directly answer the question of whether violence directed against women and girls during conflict can ever be described as indiscriminate. The discussion suggests that many more forms of illtreatment in conflict may be considered gender-based, and that the fact that the ill-treatment is gendered may reflect at least a modicum of targeting of the victim on the basis of gender, sex or both.

${ }^{200}$ Refugee Convention, note 4 above, Art. 1A(2).

${ }^{201}$ UNHCR, 'Guidelines on International Protection No. 1 - Gender-Related Persecution', note 8 above, paras. 22-34. Note that 'sex' may be relevant as a category: A. Edwards, 'Distinction, Discretion, Discrimination: The New Frontiers of Gender-related Claims to Asylum', remarks presented at Gender, Migration and Human Rights Conference, Florence, Italy (18-19 June 2012) 11, available online at http://www.unhcr.org/refworld/pdfid/4ffd430c2.pdf [Edwards, 'Distinction']. Where sex is a factor, gender may also simultaneously be a factor. There are often socially-constructed assumptions accompanying the choice of biologically female individuals for persecution. Adjudicators should be precise as to whether it is sex or gender (or both) intersecting with the Convention grounds.

${ }^{202}$ A. Roberts, 'Gender and Refugee Law' (2002) 22 Australian Yearbook of International Law 185.

${ }^{203}$ Goodwin-Gill and McAdam, The Refugee, note 193 above, 82.
} 
category. ${ }^{204}$ Where the gender of the victim dictates the manner of persecution (i.e. the persecution is carried out in a gender-specific manner, such as through rape and other forms of sexual violence, forced marriage, forced abortion, forced sterilization or forced pregnancy), but is not necessarily the reason for the persecution itself, then other Convention grounds might be more applicable. ${ }^{205}$ For example, women and girls may be punished in gender-specific ways by one party to the conflict, because of support, or perceived support, for another party to the conflict. This may be considered as persecution for reasons of actual or imputed political opinion.

\section{Membership of a Particular Social Group}

In practice, claims by women and girls tend to be considered under - and, indeed, funneled into - the category of "membership of a particular social group" or MPSG. ${ }^{206}$ The case set confirmed this: MPSG was the most common Convention ground, with political opinion, race and religion the next most common grounds (in that order). Thus, it appears that the conflict-related cases reflect the more general trend in female cases, which suffer from the disproportionate use of MPSG. ${ }^{207}$

UNHCR has defined "particular social group" as "a group of persons who share a common characteristic other than their risk of being persecuted, or who are perceived as a group by society. The characteristic will often be one which is innate, unchangeable, or which is otherwise fundamental to identity, conscience or the exercise of one's human rights." 208 Within the case set, there were examples in which "women" within a particular country

\footnotetext{
${ }^{204}$ T. Inlender, 'Status Quo or Sixth Ground? Adjudicating Gender Asylum Claims' in S. Benhabib and J. Resnick, Migrations and Mobilities: Citizenship, Borders, and Gender (New York: New York University Press, 2009), 359 [Inlender, 'Status Quo or Sixth Ground'].

205 Ibid.

206 This is the tendency in all claims by women and girls, and not only conflict-related claims: see Querton, 'I Feel Like', note 19 above, 32; Cheikh et al., note 19 above, 55 and 60; C. Querton, 'The Interpretation of the Convention Ground of 'Membership in a Particular Social Group' in the Context of Gender-related Claims for Asylum', Refugee Law Initiative, January 2012, available online at http://www.sas.ac.uk/sites/default/files/files/RLI/RLI_Working_Paper_No_3.pdf， 4; and Edwards, Transitioning Gender, note 5 above, 28.

${ }^{207}$ Chiekh et al, note 20 above, 55 .

${ }^{208}$ UNHCR, 'Guidelines on International Protection: "Membership of a Particular Social Group" within the context of Article 1A(2) of the 1951 Convention and/or its 1967 Protocol relating to the Status of Refugees', 7 May 2002, HCR/GIP/02/02, available online at http://www.unhcr.org/3d58de2da.html, para. 11 [UNHCR, 'Guidelines on MPSG']. Note that some countries require both or add an additional requirement: Querton, 'I Feel Like', note 19 above, 36; Cheikh et al., note 19 above, 62; and Crawley and Lester, note 148 above, para. 388.
} 
were identified as such a group: ${ }^{209}$ for example, Iraqi, ${ }^{210}$ Afghani, ${ }^{211}$ and Somali women. ${ }^{212}$ However, in other cases, this category was not considered to provide enough differentiation. ${ }^{213}$ In these other cases, the group was defined both by gender and other characteristics: for example, Tamil women whose husbands are missing or dead, ${ }^{214}$ Afghan women and girls related to a particular male, ${ }^{215}$ lone Somali Ashraf woman with children, ${ }^{216}$ widows of former members of the Iraqi Ba'ath party and lone women with children, ${ }^{217}$ single Somali women with children with no clan or family protection, ${ }^{218}$ and family of senior Iraqi government employees with the additional factors of being in a mixed Sunni/Shia marriage and having liberal views. ${ }^{219}$

The cases studied demonstrate that there are differing approaches as to whether and when it is appropriate to adopt the broad category of "women" as a particular social group in a given country in conflict. For example, the UK case of HM indicated that women in Somalia form a particular social group "not just because they are women, but because they are extensively discriminated against." 220 On the other hand, in the UK case of HH $\mathcal{E}$ Others, a narrower approach was adopted, in order, it appears, to be able to exclude two and accept one female claimant. Thus, the analysis did not focus, as it had in HM, on the overarching situation of women in Somalia. Rather, the focus was on clans and sub-clans because "[o]n the evidence, being a woman, without more, is not a sufficient differentiator" to place her at individualized risk on return to a city "which is in a situation of armed conflict". ${ }^{221}$ Thus, the successful claimant was classified as part of the social group "lone Ashraf woman with children", while the analysis of the others focused on clan (and not gender). ${ }^{222}$ In this case, the narrowness of the social group seemed to be a decision-making device rather than an analysis of intersectionality. Intersectionality, in and of itself, can be positive and necessary, because it recognizes the lived realities of female members of a society-who are not only

\footnotetext{
${ }^{209}$ UNHCR has indicated that 'women' can be a valid group: UNHCR, 'Guidelines on MPSG', note 208 above, para. 12 .

2101002091 [2010] RRTA 469 (7 June 2010) (Australia), para. 69 [1002091 (Australia)].

${ }^{211}$ NS (UK), note 125 above, para. 79

${ }^{212}$ HM Somalia [2005] UKIAT 00040 (26 January 2005) (UK) para. 35 [HM (UK)].

${ }^{213} \mathrm{HH}$ (UK), note 180 above, para. 352: “On the evidence, being a woman, without more, is not a sufficient differentiator to place her at such risk."

2141203764 , note 125 above, para. 85.

${ }^{215}$ JDG (Re) [2007] RPDD No. 33 (10 July 2007) (Canada), para. 133 [JDG (Canada)].

${ }^{216} \mathrm{HH}$ (UK), note 180 above, para. 369.

${ }^{217}$ NA (UK), note 181 above, paras. 93 and 97.

${ }^{218}$ AMM and Others, note 125 above, para. 631.

2191110871 [2012] RRTA 131 (6 March 2012) (Australia) paras. 90-91 [1110871 (Australia)].

${ }^{220} \mathrm{HM}$ (UK), note 212 above, para. 35.

${ }^{221} \mathrm{HH}(\mathrm{UK})$, note 180 above, para. 352.

${ }^{222}$ Ibid., paras. 349, 355 and 369.
} 
female, but are also of a particular age, religion, race, etc. ${ }^{223}$ However, if one is able to establish that a woman is being persecuted because she is a woman, or for reasons of gender, then "women" may be the more accurate particular social group. ${ }^{224}$

A default to the MPSG category sometimes also means that the nature of the conflict from which the applicant is fleeing is not analyzed at all, or not in depth. ${ }^{225}$ It is not clear from the cases why this is so, but it may be because many MPSG gender-related cases typically deal with 'private' harms in peacetime, ${ }^{226}$ such as domestic violence, forced marriage and female genital mutilation. ${ }^{227}$ As with these other sorts of harm, sometimes the MPSG analysis in conflict-related cases focused closely on the ill-treatment, and less so on the wider (and more 'public') religious, national or political aspects of the conflict and their gendered components. ${ }^{228}$ As a result, potential social groups or other applicable Convention grounds may be missed. There is also the concern that conflict-related cases raising non-typical gender issues (for example, outside of the realm of sexual violence) may mistakenly be considered as not qualifying as MPSG. Within the case set, those decisions that did consider the nature of the conflict in some depth tended to be more thorough in their consideration of the various facets of MPSG and the other Convention grounds. ${ }^{229}$

It is well-accepted that the social group cannot be solely defined by the type of current persecution. ${ }^{230}$ However, it is important to note that this does not mean that the form of persecution is irrelevant: those who have suffered past gender-related persecution such as rape "are linked by an immutable characteristic which is at once independent of [,] and the

\footnotetext{
${ }^{223}$ For example, the intersection of sex and age in the case of girls can compound the harm suffered: Edwards, 'Age and Gender Dimensions', note 18 above, 47. For cases involving girls, see Mohammed, note 125 above; and $A A(\mathrm{UK})$, note 196 above.

${ }^{224}$ Edwards, 'Distinction', note 201 above, 10-11.

${ }^{225}$ E.g. MZXQS v. Minister for Immigration and Citizenship [2009] FCA 97 (17 February 2009) (Australia) (see original decision, para. 24) [MZXQS (Australia)]; 1010754 (Australia), note 183; AHU (Re) [2007] RPDD No. 189 [AHU (Canada]; TA8-00963 (Canada), note 184 above; VA9-00148 (Canada), note 125 above; Kika (Canada), note 125 above (see original decision, para. 9); EB (UK), note 175 above; AA (UK), note 196 above; SH (Palestinian Territories) $v$ Secretary of State for the Home Department [2008] EWCA Civ 1150 (22 October 2008) (UK) [SH (UK)]; Mohammed, note 126 above; Lopez v Attorney General [2007] 504 F.3d 1341 (25 October 2007) (US) [Lopez (US)]; Mambwe, note 125 above.

${ }^{226}$ Baillot et al., 'Gaps', note 170 above, 6-7.

227 See note 21 above.

${ }^{228}$ In one case, the analysis changed from being about ill-treatment in conflict to female genital mutilation, perhaps because the decision-maker felt it was more well-established as a gender-related form of harm falling within MPSG: Mohammed, note 125 above.

${ }^{229} 1002091$ (Australia), note 210 above; 1110871 (Australia), note 219 above; 1203764 (Australia), note 125 above; JDG (Canada), note 215 above; Camara (US), note 184 above; and Kante, note 125 above.

${ }^{230}$ E.g., In re B (FC) (UK), note 125 above, para. 37; and UNHCR, 'Guidelines on MPSG', note 208 above, paras. 2 and 14.
} 
cause of[,] their current ill-treatment."231 A characteristic or an attribute expressed visibly may reinforce a finding that the individual belongs to a particular social group, but it is not a pre-condition for recognition of the group, especially given that those targeted for persecution may take pains to remain as invisible as possible. ${ }^{232}$ Thus, "persecutory action toward a group may be a relevant factor in determining the visibility of a group in a particular society." 233 This may be of special assistance in cases dealing with gender-related harm in conflict because women and girls who suffered war-related sexual violence or were conjugal slaves ('bush wives') may be stigmatized within society and therefore become part of a visible group. That said, some adjudicators seem to struggle with drawing the line between when a proposed particular social group is defined improperly by reference to conflict-related persecution, and when a past form of conflict-related persecution might be a relevant factor in creating visibility for the immutable characteristic. ${ }^{234}$

Contrary to these concerns, MPSG may also be a good category in which to analyze the sorts of conflict-related social and cultural harms identified by many women as central to their persecution. ${ }^{235}$ This is illustrated, for example, in cases identifying relational social groups, especially family. ${ }^{236}$ That said, women and girls should not be essentialized as solely social and cultural beings ${ }^{237}$ - obviously their lives are complex, and their suffering in conflict is also complex. It is for this reason that it is also important to consider the applicability of other Convention grounds in conflict-related refugee claims by women and girls. ${ }^{238}$

\footnotetext{
${ }^{231}$ In re $B(F C)$ (UK), note 125 above, para. 37.

${ }^{232}$ UNHCR, 'Matter of Valdiviezo-Galdamez, Amicus Curiae Brief In Support Of Respondent', 10 August 2012, available at: http://www.unhcr.org/refworld/docid/503653562.html , 17-18.

233 UNHCR, 'Guidelines on MPSG', note 208 above, paras. 2 and 14. This approach was applied in $L M$ Congo (UK), note 125 above, para. 111 (applicant's current vulnerability increased by fact of past rape in Congo).

${ }^{234}$ Kante (US), note 125 above, 26-27; and Gomez, note 184 above, 663-664.

${ }^{235}$ Ní Aolaín et al., On the Frontlines, note 33 above, 48 and 154.

${ }^{236}$ MZXQS (Australia), note 225 above, paras. 23-24; 1010754 (Australia), note 182 above, para. 68; 1110871 (Australia), note 219 above, para. 90; TA3-24983 and TA3-24984 IRB Canada (2 February 2005) (Canada), 6-7 [TA3-24983 and TA3-24984 (Canada)].

${ }^{237}$ Edwards, 'Transitioning Gender', note 5 above, 27.

${ }^{238}$ The importance of this was demonstrated in some cases in the case set: e.g. NA (UK), note 181 above, paras. 91-97, which considered that being an ethnic Palestinian, former member of Ba'ath party and widow of former Ba'ath member, an academic and a lone woman with children in Iraq were risk factors (being an ethnic Palestinian was enough, but the Immigration Judge looked at other risk factors for completeness). See also 1203764 (Australia), note 125 above, para. 85 .
} 


\section{Political Opinion AND the Remaining Convention Grounds}

The Convention ground of political opinion is particularly useful in conflict-related claims. This was demonstrated in the case set, which contained nine cases in which political opinion was seriously considered as an applicable Convention ground. ${ }^{239}$ This ground captures different ways in which a woman or girl may have political opinion imputed to her by a party to the conflict. This may occur when the claimant worked with, or for, a political party or a politician in her country of origin: for example, in the UK case of LM Congo, the applicant had served as secretary for youth, and in other roles, for an opposition group. ${ }^{240}$ As well, persecutors may impute political opinion based on familial relationships. In the Australian case of MZXQS, the applicants claimed a well-founded fear of persecution because of their link to their sister, a well-known Tamil opposition Member of Parliament in Sri Lanka representing an LTTE-controlled area. ${ }^{241}$ The original tribunal considered this claim as falling under MPSG, and dismissed the claim on this ground. ${ }^{242}$ The court found that the tribunal had incorrectly characterized the claim, which was actually a claim of imputed political opinion on the basis of their relationship with their sister. ${ }^{243}$ In the New Zealand case of $73894 \mathrm{et} \mathrm{al.,} \mathrm{the} \mathrm{court} \mathrm{found} \mathrm{that} \mathrm{the} \mathrm{female} \mathrm{applicant} \mathrm{was} \mathrm{at} \mathrm{risk} \mathrm{due} \mathrm{to} \mathrm{the}$ political activities of her husband, who helped Rwandan Tutsis flee the DRC. ${ }^{244}$ Another way in which political opinion may be imputed to a woman or a girl is for holding, or appearing to hold, views different from those of the warring factions. ${ }^{245}$ In the UK case of LM Iraq, the applicant was perceived by Iraqi militia as supporting or collaborating with the West, in part because she was a high-profile working woman who did not wear the hijab at work. ${ }^{246}$ In addition, political opinion has been deemed to be imputed based on racial or ethnic identity: in the Australian case of 1203764 , the tribunal found that there was a real risk that the

${ }^{239}$ MZXQS (Australia), note 225 above; 0901064 (Australia), note 182 above; 1012015 [2011] RRTA 245 (1 April 2011 (Australia) [1012015 (Australia)]; 1203764 (Australia), note 125 above; TA3-24983 and TA3-24984 (Canada), note 236 above; 73894 et al. (New Zealand), note 125 above; LM Iraq CG [2006] UKAIT 00060 (26 July 2006) (UK) [LM Iraq (UK)]; LM Congo (UK), note 125 above; but note Lopez, note 225 above.

${ }^{240}$ LM Congo (UK), note 125 above, para. 107. In this case, the political opinion of the applicant's political superior was imputed to her: para. 114.

${ }^{241}$ MZXQS (Australia), note 225 above, para. 4.

242 Ibid., para. 11.

243 Ibid., para. 24. The Tribunal was therefore asked to deal with the political opinion claim: para. 28.

24473894 et al. (New Zealand), note 125 above, paras. 5, 32, 102, 103, 106. Similarly, in TA3-24983 and TA324984 (Canada), note 236 above, 1, the applicant was granted refugee status "by reason of her perceived political opinion, that being viewed as a non-collaborator by the FARC", due to the actions of her expartner..

${ }^{245}$ LM Iraq (UK), note 239 above, para. 73.

${ }^{246} \mathrm{Ibid}$., paras. 67,73 and 75 . This was considered as perceived political opinion (rights of Iraqi women): para. 73. 
applicant, a Tamil from the north, would be sexually assaulted or otherwise harmed if she returned to Sri Lanka, for reasons of the political opinion imputed to her (membership of or sympathy for the LTTE). ${ }^{247}$

The applicant herself may not classify her actions as political. It is therefore important for refugee decision-makers to recognize when a claim is, in fact, based on political opinion by examining the applicant's actions. For example, in 73894 et al., the female applicant, who was from the DRC, indicated that she "has not been interested in politics". ${ }^{488}$ However, she and her husband disagreed with the government's policy of persecuting Rwandan Tutsis, and the applicant therefore helped to shelter Rwandan Tutsis (while her husband helped them to flee). ${ }^{249}$ The Refugee Status Appeals Authority characterized this as "an overt political act opposing the policies of the Kabila regime." 250 As a result of her actions and those of her husband, her home was searched several times and the female members of her family were raped and sexually abused. ${ }^{251}$ Despite the conclusion that sheltering Rwandan Tutsis was a political act, the Authority felt that the applicant's case was derivative of her husband's and based its grant of refugee status on imputed political opinion (due to her husband's actions) as a result. ${ }^{252}$

Women's political activity during conflict may take forms different from that associated with male political activity - and the political activity by women needs to be recognized as such. In the US case of Lopez, the applicant joined the Colombian Liberal Party, providing humanitarian assistance to residents of poor communities and conducting seminars on the principles of the Liberal Movement. ${ }^{253}$ She was subsequently attacked by the FARC in retaliation for these activities. ${ }^{254}$ The Immigration Judge found that these activities were "community-based and not political in nature", and therefore the Convention ground of political opinion did not apply. ${ }^{255}$ This categorization of women's political activities as something other than political - such as community work - is also recognized to be a serious problem for non-conflict-related female refugee claims. ${ }^{256}$

\footnotetext{
2471203764 (Australia), note 125 above, para. 84. See also 1012015 (Australia), para. 239 above.

24873894 et al. (New Zealand), note 125 above, para. 15.

${ }^{249}$ Ibid., paras. 95 and 96.

${ }^{250} \mathrm{Ibid} .$, para. 96.

${ }^{251} \mathrm{Ibid} .$, para. $41,45$.

${ }^{252} \mathrm{Ibid}$., paras. 100-104. The grant of status is found in para. 106. There appears to be a typographical error in the first sentence of para. 106, as the second sentence refers to a grant of refugee status.

${ }^{253}$ Lopez, note 225 above, 1343.

${ }^{254} \mathrm{Ibid}$.

${ }^{255}$ Ibid., 1344. Petition for review on this point not granted.

${ }^{256}$ Crawley, Refugees and Gender, note 21, 79-83.
} 
Finally, the cases in the case set demonstrated that, in the context of racially- or religiouslymotivated conflicts, the Convention grounds of race and religion are particularly helpful. ${ }^{257}$ While the Convention ground of nationality was not represented in the case set, it also would be a useful ground in the context of nationality-driven conflicts.

\section{LESSONS LEARNED}

This Part has explored the hazards associated with over-reliance on MPSG in cases dealing with both gender and conflict, such as a tendency toward creating artificial sub-groups of women rather than rely on "women" generally. ${ }^{258}$ As well, there appears to be a focus on the 'private' side of the gender-related harms, to the detriment of an analysis of the nature of the conflict. On the other hand, there are benefits to using MPSG, as it is suited to drawing attention to social and cultural harms. It is also important for adjudicators to avoid an automatic reliance on MPSG and instead consider the other Convention grounds, especially political opinion. On political opinion, while this appears to be a particularly helpful ground in conflict-related cases, at least one case illustrated that it is crucial that adjudicators realize that female political activity may not always look like 'standard' male political activity. Race, religion and nationality may also be useful grounds when considering cases stemming from racial, religious or nationality-driven conflicts.

\section{LACK OF STATE PROTECTION}

When adjudicators evaluate the risk of future persecution in gender-related claims, one issue they assess is whether the applicant can benefit from State protection against the actions of non-State actors. The case set revealed some gender-sensitive analysis of whether or not State protection is available, especially consideration of the dangers faced by a lone woman (sometimes with children) returning to a conflict-ridden society rife with discrimination against women, in which women (and girls) may be common targets for gender-related violence (such as rape, forced prostitution and trafficking). ${ }^{259}$ However, there were also disturbing examples of non-sensitivity. In the UK case of $P S$, the second immigration judge

\footnotetext{
${ }^{257}$ On race, see 1203764 (Australia), note 125 above, para. 85; NA (UK), note 181, para. 91; on religion, see JXV (Canada), note 125 above, para. 89.

${ }^{258}$ Edwards, 'Distinction', note 201 above, 10.

${ }^{259}$ E.g. NA (UK), note 181 above, paras. 97-98; $A A$ (UK), note 196, 1; and AMM and Others, note 125 above, para. 631. See also Judgment W 2 K 11.30330, Administrative Court of Würzburg (Germany), 16 February 2012, available online (in German) at http://www.asyl.net/fileadmin/user upload/dokumente/19769.pdf , in which the fact that a woman was single and lacked protection of a male family member led to a serious and individual threat for the applicant in Afghanistan and there was no meaningful internal protection alternative.
} 
found that the Tamil applicant's rapists, despite being Sri Lankan soldiers, were "rogue" and comparable to "three civilian criminals". ${ }^{260}$ The judge concluded that there was no threat of future persecution, and that, in the event the applicant had difficulties from them again, she could seek State protection in the government-controlled area since the soldiers' actions were not sanctioned by the Sri Lankan government. ${ }^{261}$ This was overturned on appeal, with the judges finding that "[t]he whole point was that, unlike ordinary criminals, the soldiers were in a position to commit and repeat their crime with no apparent prospect of detection or punishment." 262 The lesson from this case is that the analysis of future risk must be undertaken in a gender-sensitive manner with a full appreciation of the nature of the conflict, including whether the State permits impunity for gender-related violations.

One key issue arising in the cases in this study related to the impact the end of a conflict had on consideration of the risk of future persecution and State protection. This is demonstrated in the US case of Mambwe, in which the end of the civil war in Angola was considered to eliminate any future risk of persecution. ${ }^{263}$ This was despite the applicant's assertion that the civil war "was not put to rest" by the peace accord and disarmament of UNITA. ${ }^{264}$ Rather than consider persecutory risks in Angola facing young female rape victims of UNITA with a child by rape who have no relatives, the court instead only considered whether UNITA is still a military threat. ${ }^{265}$ Thus, State protection from sources of persecution other than UNITA were not considered, even though she is likely to face severe societal stigma from those on both sides of the conflict. ${ }^{266}$ It is important to recognize that the timelines of persecution do not necessarily accord with the timeline of cease-fires or peace agreements: "Regime changes may be less effective in protecting women from such dangers [as rape] than they are for men". ${ }^{267}$ The Canadian Guidelines correctly state: "A change in country circumstances, generally viewed as a positive change, may have no impact, or even a negative impact, on a woman's fear of gender-related persecution." 268 Peace processes may marginalize women's concerns and may not touch deep-seated discrimination directed against women and girls. ${ }^{269}$ When considering risk of future persecution in cases where conflict has ceased, it is relevant

\footnotetext{
${ }^{260}$ PS (UK), note 125 above, para. 7.

${ }^{261}$ Ibid.

262 Ibid., para. 8.

${ }^{263}$ Mambwe (US), note 125 above, 4.

264 Ibid.

${ }^{265}$ Ibid., 4-5.

${ }^{266}$ See also $A A(\mathrm{UK})$, note 196 above, 4, noting that the future persecution feared (in this case, forced prostitution) can be of a different category from that on which the original claim was based.

${ }^{267} N(\mathrm{UK})$, note 148 above, para. 58.

${ }^{268}$ Canada, 'Guidelines', note 12 above, s. C(3) 'Evidentiary Matters'.

${ }^{269}$ Ní Aolaín et al., On the Frontlines, note 33 above, 46.
} 
for an adjudicator to consider whether conflict-related sexual violence has been addressed in any cease-fire or peace agreement in the country of origin: ${ }^{270}$ if it has not, then this is a potential indicator of State unwillingness to counter sexual violence.

\section{PROCEDURAL AND EVIDENTIARY ISSUES}

As Crawley notes, procedural and evidential barriers "often inhibit women's access to the determination process and may serve to limit the quality of information gathered about the claim and, in turn, the quality of the decision-making process." ${ }^{271}$ This proved true in the cases reviewed in the case set. The most challenging issue arising in conflict- and genderrelated claims appears to be lack of gender-sensitive country of origin information, followed closely by inability to establish credibility.

\section{COUNTRY OF ORIGIN INFORMATION}

The lack of gender-sensitive country of origin information is an overarching problem affecting all gender-related claims, ${ }^{272}$ but the problem seems to be compounded in conflictrelated claims. Where there was adequate gender- and conflict-related country of origin information available to decision-makers, the analysis of the cases tended to be more thorough and sensitive. ${ }^{273}$ Where such information seemed to be lacking, the analysis was less thorough and more speculative, and the female applicants had serious difficulties proving their cases. ${ }^{274}$

Female claimants typically would benefit from: pre-conflict information on the legal, political, social, cultural and economic position of women and girls and consequences for non-adherence to socio-cultural gender norms, information on how these aspects have changed for women and girls during the conflict, the incidence and forms of reported

\footnotetext{
${ }^{270}$ For examples of how this might be done, see UNDPA, “Guidance for Mediators', note 28 above.

${ }^{271}$ Crawley, Refugees and Gender, note 21 above, 199.

272 Querton, 'I Felt Like', note 19 above, 32; HRW, 'Fast-Tracked', note 19 above, 44 and 47-48; Crawley and Lester, note 148 above, para. 653; Cheikh et al., note 19 above, 89; H. Crawley, 'Thematic Review on the Coverage of Women in Country of Origin Information (COI) Reports', 19 September 2011, available online at http://icinspector.independent.gov.uk/wp-content/uploads/2011/02/Evaluation-of-the-Country-of-OriginReport-on-Women3.pdf ,133-144 [Crawley, 'COI'].

${ }^{273}$ E.g., 110871 (Australia), note 219 above, para. 86; NS (UK), note 125 above, 10-17; LM Iraq (UK), note 239 above, paras. 38-39 and 63-64; HH (UK), note 180 above, 187, 188 and 192; NA (UK), note 181 above, paras. 31 and 40; LM Congo (UK), note 125 above, para. 77; and SS (UK), note 124 above, 16.

${ }^{274}$ E.g., AHU (Canada), note 225 above; TA8-00963 (Canada), note 184 above; VA9-00148 (Canada), note 125 above; Kika (Canada), note 125 above; Lopez (US), note 225 above; Camara (US), note 184 above; and Kante (US), note 125 above.
} 
violence (in both the private and public spheres) against women and girls pre-conflict and during conflict, the protection available to them during conflict or post-conflict, any penalties imposed on those who perpetrate the violence, and detailed information about the nature of the conflict and the parties to the conflict. ${ }^{275}$ It is not always possible to collect this information on countries at peace, but getting accurate, up-to-date information on the situation of women and girls during a conflict can be extremely difficult, and if it is collected, it likely reflects under-reporting and therefore under-estimation. ${ }^{276}$

The cases in the case set tended to rely on specific types of country of origin information, especially from UNHCR, ${ }^{277}$ so it is crucial that UNHCR continue to provide as much guidance in this respect as possible. ${ }^{278}$ Other sources included international nongovernmental organizations ${ }^{279}$ and certain United Nations reports. ${ }^{280}$ There is certainly scope for improving country of origin information on both gender and conflict issues to include a wider range of UN documents, such as Security Council resolutions referring to gender-related ill-treatment, ${ }^{281}$ reports of the UN Secretary-General written pursuant to Security Council resolution 1889 and its indicators, ${ }^{282}$ UN Secretary-General reports pursuant to resolution $1960^{283}$ and other UN reports providing qualitative and quantitative information on women and girls in conflict settings. As well, reports from other international organizations, such as the International Committee of the Red Cross, ${ }^{284}$ should be considered. Decisions or judgments of international criminal tribunals might also be

\footnotetext{
${ }^{275}$ Ní Aolaín et al., On the Frontlines, supra note 33 at 45-46; Crawley, 'COI', note 272 above, 133-134.

${ }^{276}$ Chiekh at al, note 19 above, 89; and UN Women, note 88 above, 83.

277 E.g., NS (UK), note 125 above, 13-14.

${ }^{278}$ E.g., UNHCR, ‘Interim Eligibility Guidelines for Assessing the International Protection Needs of AsylumSeekers from Côte d'Ivoire', 15 June 2012, HCR/EG/CIV/12/01, available online at http://www.unhcr.org/refworld/docid/4fa7c1c92.html, 28-32.

279 E.g. NS (UK), note 125 above, 13 (Amnesty International) and International Commission of Jurists).

${ }^{280}$ E.g. reports from the UN Commission on the Status of Women: NS (UK), note 125 above, 12.

${ }^{281}$ Since the adoption of Resolution 1325, the Security Council has made reference in its country-specific resolutions to gender-based violence directed against women and girls. E.g. in 2012: UNSC Res. 2035 (2012), 17 February 2012, para. 8; UNSC Res. 2040 (2012), 12 March 2012, para. 7.

282 The indicators are set out in: Report of the United Nations Secretary-General, 'Women and Peace and Security,' 28 September 2010, S/2010/498, Annex. Each year, the Secretary-General addresses one third of these indicators in his reports: e.g., Report of the United Nations Secretary-General, 'Women and Peace and Security', 29 September 2011, S/2011/598 (2011).

283 The Secretary-General's reports pursuant to Resolution 1960 include a discussion of conflicts in which sexual violence has been documented: Report of the United Nations Secretary-General, 'Conflict-related sexual violence,' 13 January 2012, S/2012/33, paras 17-57 and Annex.

${ }^{284}$ E.g. ICRC, ‘Women Facing War', note 87 above.
} 
helpful. ${ }^{285}$ Finally, reports from international and domestic nongovernmental women's organizations (including those located in the country of origin) should be considered. ${ }^{286}$ All refugee-receiving countries should aim to systematically collect and make available to applicants and their representatives up-to-date and accurate information on the situation and experiences of women and girls, including in conflict. ${ }^{287}$ As well, where there is a lack of information, decision-makers should be cautioned against drawing speculative conclusions or assuming lack of persecution. 288

\section{CREDIBILITY}

The second most challenging issue relates to credibility. Within the case set, a number of claims were not accepted due to rulings of lack of credibility, either at the initial stages or on appeal. ${ }^{289}$ This was due to a number of factors, most often inconsistencies ${ }^{290}$ or perceived implausibilities in testimony, 'incorrect' demeanor (for example, being matter-of-fact when the adjudicator expects an applicant to be distressed), ${ }^{291}$ or lack of corroborative country of origin information. When found credible, it was often due to a combination of 'correct' demeanor, ${ }^{292}$ relative consistency in the applicant's story ${ }^{293}$ and corroborative country of

\footnotetext{
${ }^{285}$ However, their utility may be limited given the length of time between arrest and judgment, and the prospective nature of the refugee test: UNHCR, 'Complementarities between International Refugee Law, International Criminal Law and International Human Rights Law: A UNHCR Perspective on the Meaning(s) of Persecution and the use of Criminal Evidence in Asylum Adjudications', April 2011, available online at http://www.unhcr.org/refworld/docid/5035fddc2.html , 15.

${ }^{286}$ Crawley, 'COI', note 272 above, 137 and 142.

287 Ibid., 134.

288 Ibid., 139; Cheikh et al., note 19 above, 91.

${ }^{289}$ E.g. 0901064 (Australia), note 182 above (found credible on appeal), 1002652 (Australia), note 184 above; 1203764 (Australia), note 125 above (on rape); TA3-24983 and TA3-24984 (Canada), note 236 above; JDG (Canada), note 215 above; MA5-05605 [2007] RPDD No. 26 (26 October 2007) (Canada); TA6-00022 (Canada), note 125 above; MA8-00516 [2009] RPDD No. 148 (6 May 2009) (Canada); VA8-01482 (Canada), note 125 above; TA8-18792 (Canada), note 184 above; MA8-07482 (Canada), note 125 above; Kika (Canada) (at initial stage), note 125 above; $E B$ (UK), note 175 above (found credible on appeal); BK (UK), note 125 above; HH (UK), note 180 above; AMM and Others, note 125 above; Mohammed (US), note 125 above (at initial stage); and Mambwe (US), note 125 above.

${ }^{290}$ In one case involving a claim of sexual violence, the decision-maker accepted that women can have valid reasons for giving unclear evidence about rape, but felt that the applicant's inconsistencies were too large: BK (UK), note 125 above, paras. 524 and 527.

${ }^{291}$ E.g. Refugee Appeal No. 75410 (7 March 2005) (New Zealand) [75410 (New Zealand)], the applicant presented evidence about her fiancé's disappearance in a matter-of-fact manner, but the adjudicator felt that she should have been distressed (para. 55), so found her not credible (54-57).

${ }^{292}$ E.g., 1110871 (Australia), note 219 above, para. 86; and TA3-24983 and TA3-24984 (Canada), note 236 above, 4 (gave evidence in a straightforward and consistent manner).

${ }^{293}$ Complete consistency is not expected: 0901064 (Australia), note 182 above, para. 63.
} 
origin information. ${ }^{294}$ The case set mirrors concerns expressed about similar experiences with claims by women and girls more generally. ${ }^{295}$ For example, previous studies have shown that a majority of female claimants are simply not believed at first instance. ${ }^{296}$ This is due to many factors: a hostile environment negatively affecting how detailed the applicant can be in explaining her case; ${ }^{297}$ undue concentration on perceived inconsistencies without consideration for the impact of trauma and dislocation on memory or for culturally different ways of expression; ${ }^{298}$ disincentives for women and girls to reveal sexual violence (due to being traumatized, feelings of shame, or fear of stigma) with late disclosure of sexual violence sometimes being held against the applicant, ${ }^{299}$ difficulty in evidencing genderspecific forms of harm and the absence of State protection; 300 and incorrect assumptions about the meaning of an applicant's demeanor. ${ }^{301}$ Credibility findings are clearly affected by gender-insensitive refugee claim processes and procedures.

\section{LESSONS LEARNED}

The case set revealed two major problems facing women and girls making refugee claims based on a combination of gender- and conflict-related harm. The first challenge for these applicants was in accessing and presenting accurate and up-to-date country of origin information containing relevant facts about the conflict and its gender dimensions. The second difficulty was in establishing credibility in the claim procedure. These problems are not specific to conflict-related claims, but the fact that the claim involves conflict may make it even more difficult to access reliable and gender-sensitive country information. Conflictrelated trauma may compound this lack of access to information, making it more difficult to establish credibility. There have been many recent studies outlining proposed improvements to domestic refugee determinations processes involving either women and girls, or gender-

\footnotetext{
${ }^{294}$ E.g. 1012015 (Australia), note 239 above; 1010754 (Australia), note 182 above; 1110871 (Australia), note 219 above; JXV (Canada), note 125 above; 73894 et al. (New Zealand), note 125 above; 75410, New Zealand, note 291 above; 76464 and 76465 (New Zealand), note 125 above; and AB (New Zealand), note 125 above.

295 E.g. Muggeridge and Maman, 'Unsustainable', note 19 above, 34-43; Querton, 'It Feels Like', note 19 above, 55-63; and Cheikh et al., note 19 above, 77-88.

${ }^{296}$ Muggeridge and Maman, 'Unsustainable', note 19 above, 5 (majority of women simply not believed at first instance).

${ }^{297}$ HRW, 'Fast-Tracked', note 19 above, 42.

${ }^{298}$ Querton, 'I Feel Like', note 19 above, 38. E.g., HRW, 'Fast-Tracked', note 19 above, 41, recounts the case of Jane S., who was told that her accounts of being raped and the killing of her family in Sierra Leone were not believed because she could not remember the dates.

${ }^{299}$ Cheikh et al., note 19 above, 81; Querton, 'I Feel Like', note 19 above, 41-44. But see: 1203764 (Australia), note 125 above, para. 23, accepting that delays in speaking about rape need not affect credibility.

${ }^{300}$ Cheikh et al, note 19 above, 77, 79 and 172.

${ }^{301}$ Querton, 'I Feel Like', note 19 above, 41; and HRW, 'Fast-Tracked', note 19 above, 40-41.
} 
based claims more generally. ${ }^{302}$ If implemented, such improvements are likely to positively impact conflict-related claims. That said, (more) conflict-specific guidance for decisionmakers might be necessary, especially with respect to the issues of establishing credibility and providing evidence.

\section{CONCLUSIONS}

Women and girls fleeing conflict clearly face a number of obstacles to presenting a successful claim for refugee status. These obstacles are similar to those faced by female claimants fleeing peacetime, but are compounded in conflict-related cases. Part 2 examined the character and effects of conflict on women and girls, demonstrating that, while individual experiences will vary, there are common threads. These common threads mean that, while women and girls may suffer from similar deprivations and violations as men and boys, their experiences of conflict may be different due to the underlying effects of gender discrimination. In addition, there are ways in which women and girls may be targeted for illtreatment that is different from that faced by men and boys.

This study began by asking three questions: can violence directed against women and girls during conflict ever be described as indiscriminate (and therefore not persecutory for the purposes of the Refugee Convention); on what legal basis, if any, could a woman or girl fleeing conflict meet the definition of 'refugee'; and what problems do women and girls fleeing conflict face when making refugee claims, and are these problems different from those faced by female claimants fleeing peacetime ill-treatment?

The question of whether violence directed against women and girls during conflict can ever be described as indiscriminate falls directly within the adjudicator's consideration of the applicant's claim of persecution. In Part 3, this study found that a number of decisionmakers classify gender-related violence as part of the general indiscriminate consequences of conflict, and therefore not targeted enough to amount to past persecution or present a risk for future persecution. This study also considered that refugee decision-makers may be less likely to classify such violence as untargeted if they have an in-depth understanding of both the gendered nature of the conflict and the nature of gender-related discrimination before, during and after the conflict. Plainly, this points to the need for better and more standardized dissemination of gender-sensitive country of origin information, including information on the treatment of women and girls in that country's conflict. The fact that a

\footnotetext{
302 E.g. Cheikh et al., note 19 above; Querton, 'I Feel Like', note 19 above; Muggeridge and Maman, 'Unsustainable', note 19 above; HRW, 'Fast-Tracked', note 19 above; UNHCR, 'Improving Asylum Procedures - Gender', note 19 above.
} 
form of ill-treatment is gendered may demonstrate that an individual was targeted as a woman or a girl in that conflict, which then raises the question of whether this sort of targeting always - or only sometimes - rises to the level required. Thus, the preliminary answer to the question is that, while it is not clear whether there are forms of gender-related ill-treatment in conflict that may properly be considered to be indiscriminate, it is evident that more cases of such ill-treatment should be considered as targeted (rather than indiscriminate) than is currently the case.

The question of the legal basis, if any, on which a woman or girl fleeing conflict can meet the definition of 'refugee', was considered in Parts 3, 4 and 5. Part 3 found that some forms of gender-related ill-treatment in conflict have been found to amount to persecution, especially rape. And yet, many applicants have difficulty establishing conflict-related rape as persecution for two reasons: first, some adjudicators incorrectly characterize rape in conflict as a 'private' act and therefore outside the realm of persecution; and second, not enough attention is paid by decision-makers to the after-effects of past rape in creating related yet different future risks of persecution. Another challenge relates to the current relatively narrow perception of what qualifies as a gender-related form of persecution in conflict. Rape and other forms of sexual violence are recognized, but it is less common for decision-makers to recognize non-sexual gendered violations and seemingly gender-neutral acts (like enslavement) carried out through gendered means or having gender-specific effects. In other words, there are currently certain obstacles that may make it more difficult than it should be for a female claimant fleeing conflict to prove that she has a well-founded fear of persecution. Refugee decision-makers should listen more carefully for, and draw out, gender-related ill-treatment, while at the same time respecting that women may identify harm in gender-differentiated ways.

Part 4 continued the discussion of obstacles, this time in relation to the Convention grounds. As with all gender-related claims, there is a tendency for adjudicators to rely on MPSG as the main ground for analysis. The use of MPSG can be useful, but it can also be problematic. For example, while some decision-makers have accepted that 'women' can be a valid particular social group, others create narrower, sometimes artificial, sub-groups, which can distort the resulting analysis. As well, some adjudicators seem to focus on the 'private' side of the gender-related harms, to the detriment of an analysis of the nature of the conflict. These obstacles may be overcome with a more fulsome focus on the other Convention grounds. Political opinion may in fact be the most useful and applicable ground for analysis, given the extreme politics inherent in conflict. As well, the remaining grounds may also be helpful when considering cases stemming from racial, religious or nationality-driven conflicts. Again, these findings pointed to the importance of ensuring that all those involved in the 
refugee determination process have access to, and use, gender-sensitive country of origin information, including information on the nature of the conflict.

Part 5 considered obstacles - and possibilities - arising with the consideration of whether or not there is State protection in the country of origin. There is some positive case law considering the risks to lone females returning to conflict-affected countries of origin. On the other hand, there are also cases that failed to understand the actual vulnerabilities of women and girls in conflict in relation to their own State. As well, there is some positive case law recognizing that a cease-fire or peace agreement does not necessarily mean the end of gender-related persecution in a country of origin, but there is also case law demonstrating that some decision-makers do not pay enough attention to the actual post-conflict circumstances of women and girls. These findings confirmed that women and girls fleeing conflict may face more difficulties than they should in demonstrating lack of State protection and risk for future persecution.

Finally, while the question of problems women and girls fleeing conflict face when making refugee claims was explored, in part, through the answers to the questions above, it was also considered in Part 6. That Part examined procedural and evidentiary difficulties arising in conflict- and gender-related claims. Women and girls face significant hurdles in accessing and presenting accurate and up-to-date country of origin information containing relevant information on the conflict and its gender dimensions. They also often encountered problems establishing their credibility in the claim procedure. Sometimes this was because they did not have relevant country of origin information to corroborate their stories; sometimes it was because they reacted differently than a decision-maker expected and sometimes it was because they were not consistent in their stories. Some decision-makers took into account the effects of conflict-related trauma on memory or demeanor, but others did not. The discussion in Part 6 illustrated that claims that were both gender- and conflictrelated faced many of the same difficulties faced by gender-related claims stemming from peacetime: access to helpful country of origin information and establishing credibility. However, these problems may be compounded by the fact of the conflict: the complex layering of harms in conflict may create deep trauma and therefore difficulties in presenting a claim in a coherent and consistent manner, and the conflict may prevent the gathering of gender-sensitive information helpful in supporting a gender-related refugee claim. The procedural and evidentiary recommendations already made in the current literature on how to improve the domestic refugee claim process for women and girls are very important, and just as applicable, for the sub-category of conflict-related claims. In addition, it may be helpful to provide decision-makers with conflict-specific procedural and evidentiary guidance. 
In conclusion, while there are welcome developments in international and domestic refugee law under which claims by women and girls fleeing conflict have been accepted, there is also much room for improvement. There is a need for a deeper understanding of gender-related persecution, such that seemingly indiscriminate, and/or seemingly gender-neutral, illtreatment of women and girls is more correctly recognized as persecution. There is also a need for expanded conceptions of the Convention grounds as they relate to women and girls fleeing conflict. Finally, while women and girls fleeing conflict face problems similar to those making peacetime-related claims, they may also face specific conflict-related evidentiary and credibility-related hurdles. These hurdles might be (partly) removed by implementing gender-related improvements already recommended in other studies to all gender-related claims, but it may be necessary for decision-makers to be provided with (more) conflict- and gender-specific guidance on credibility and evidence. Finally, there is also a need for deeper study of the experiences of female applicants putting forward joint gender- and conflictrelated refugee claims: it may well be that they face even more significant barriers than have yet been identified. 